\title{
Deformation-Induced and Reaction-Enhanced Permeability in Metabasic Gneisses, Iona, Scotland: Controls and Scales of Retrograde Fluid Movement
}

\author{
Tim J. Dempster $\mathbb{D}^{1}{ }^{1}$ Allan D. Hollinsworth, ${ }^{1}$ Euan McIntosh, ${ }^{1}$ Shannon Edgar, ${ }^{1}$ \\ John W. Faithfull (iD, ${ }^{2}$ and Daniel Koehn ${ }^{1}{ }^{1}$ \\ ${ }^{1}$ School of Geographical and Earth Sciences, University of Glasgow, Glasgow G12 8QQ, UK \\ ${ }^{2}$ The Hunterian, University of Glasgow, Glasgow G12 8QQ, UK \\ Correspondence should be addressed to Tim J. Dempster; tim.dempster@glasgow.ac.uk
}

Received 17 March 2020; Accepted 3 June 2020; Published 28 January 2021

Academic Editor: Antonio Benedicto

Copyright (c) 2021 Tim J. Dempster et al. This is an open access article distributed under the Creative Commons Attribution License, which permits unrestricted use, distribution, and reproduction in any medium, provided the original work is properly cited.

\begin{abstract}
The spatial distribution of greenschist-facies retrograde reaction products in metabasic gneisses from Iona, western Scotland, has been investigated. The retrograde products may be broadly accounted for by a single reaction, but their different spatial and temporal development indicates that a series of reactions occur with significantly different scales of metasomatic transfer. After initial fluid influx linked to deformation-induced high permeability, reaction-enhanced permeability, coupled to cycling of fluid pressure during faulting, strongly controls the pervasive retrogression. Ca-plagioclase and pyroxene in the gneisses are replaced by albite and chlorite in pseudomorphic textures, and this is followed by localized epidotization of the albite. Two main generations of epidote are formed in the gneisses. Epidosite formation is associated with prominent zones of cataclasite indicating a strong link between faulting and fluid influx. In contrast, complete alteration of albite to epidote in the host metabasic gneisses is spatially complex, and areas of pervasive alteration may be constrained by both epidote-rich veins and cataclasites. In other instances, reaction fronts are unrelated to structural features. Volume changes associated with individual stages of the reaction history strongly control the localized distribution of epidote and the earlier more widespread development of chlorite and albite. Such behaviour contrasts with adjacent granitic gneisses where epidotization is restricted to local structural conduits. Many small-scale mineralized fractures with evidence of having previously contained fluids do not enhance the pervasive retrogression of the metabasic gneisses and represent conduits of fluid removal. Retrogression of these basement gneisses is dominated by a complex combination of reaction-enhanced and reaction-restricted permeability, kinetic controls on the nucleation of reaction products, changes in fluid composition buffered by the reactions, and periodic local migration of fluids associated with fault movements. This combination generates spatially complex patterns of epidotization that are limited by cation supply rather than fluid availability and alternations between focused and pervasive types of retrogression.
\end{abstract}

\section{Introduction}

Fluids in the Earth's crust are crucially important in the transport of solutes and the precipitation of mineral deposits and also play a key role in controlling metamorphic transitions and influencing crustal properties, such as density, geochemistry, rheological characteristics, and geothermal gradients [1-11]. In near-surface permeable crustal rocks, fluids may circulate in vigorous hydrothermal systems, and significant geochemical modification of the host rocks can occur [12-15]. Processes of fluid infiltration in rocks undergoing prograde metamorphism have also been well constrained, highlighting the importance of deformation and the effects of fluid composition [16-19]. The movement of high-temperature fluids in relatively impermeable stable basement rocks is less commonly investigated [20], despite their importance as hosts for storing nuclear waste $[21,22]$. Fluids may potentially be introduced in such rocks through 
zones of brittle failure or via grain boundary infiltration [23] and are commonly consumed in retrograde reactions. Such reactions are kinetically challenging, but proposed fast reaction rates suggest that a fluid phase is unlikely to persist in crystalline basement rocks [24]. Retrograde reaction products may either facilitate further fluid influx through reaction-enhanced permeability or provide effective seals to fluid transport [25-27]. There are many important studies of the modification of basic igneous rocks in the ocean crust $[2,28,29]$ and the interaction between fluid conduits and their host lithologies [30, 31]. However, there are few investigations of retrograde metamorphic controls in the highgrade metabasic basement lithologies that characterize deeper parts of the continental crust $[32,33]$. Equally, although the effects of variable fluid pressure are recognized within brittle fault structures (e.g., $[34,35])$, the interaction of such fluids with adjacent reactive host rocks has received relatively little attention.

This study examines the relative importance of deformation-induced permeability and reaction-enhanced permeability in controlling fluid access to crystalline basement lithologies in a high-grade gneiss block exposed on Iona on the west coast of Scotland. In particular, we combine field observations with petrographic and textural analysis based on optical and SEM/EDX examination of polished thin sections to investigate the factors controlling the alteration of plagioclase to epidote, a reaction of some significance to studies of hydrothermal alteration of the oceanic crust [13, 36-39].

\section{Geological Background}

Abundant intermediate to granitic orthogneisses and rare paragneisses [40] are exposed along the western coast of the island of Iona, Inner Hebrides, western Scotland (see Figure 1). These are thought to be Lewisian gneisses, part of the Coll-Tiree block [41]. In this locality, the Lewisian gneiss complex is dominated by banded $\mathrm{K}$-feldspar-rich granitic gneisses with abundant ca. 20\% amphibole-rich mafic gneisses, which define $\mathrm{m}$ - to $\mathrm{dm}$-scale layers and enclaves within the felsic host $[40,42]$. Unpublished $\mathrm{U}-\mathrm{Pb}$ zircon ages reported in McAteer et al. [43] constrain the age of the gneiss complex to be ca. $2700 \mathrm{Ma}$ with some younger granite pegmatite sheets crystallizing at ca. $1750 \mathrm{Ma}$. The gneisses are overlain by the Iona group, a sequence of sandstones with a basal conglomerate (see Figure 1). To the east of Iona, skerries of the Caledonian Ross of Mull granite (418 $\pm 5 \mathrm{Ma}$, Oliver et al. [44]) are present approximately $1.5 \mathrm{~km}$ from the exposures studied in this investigation (see Figure 1).

The Sound of Iona (see Figure 1) coincides with the trace of a proposed normal fault, which here cuts out the earlier Moine Thrust [45], a major Caledonian terrane boundary in Scotland [46]. The majority of studies on the Lewisian gneisses of western Scotland have focused on their origin and high-temperature metamorphic evolution (e.g., [47]), and there have been relatively few studies of greenschistfacies retrograde transformations (e.g., [48]). Most of the latter have focused on their structural importance and interaction of these transformations with fault zone activity (e.g., [49]). Few have highlighted the partial greenschist-facies retrogression of the gneisses [50] as a record of fluid infiltration into such basement lithologies. A wide variety of fault rocks (cf. [51]) are present in the gneisses of Iona, ranging from incohesive fault gouge to cataclasite and mylonite and locally abundant $\mathrm{cm}$-thick pseudotachylite. Pseudotachylite is relatively abundant in other areas of the Lewisian gneiss outcrop, including parts of the Outer Hebrides (e.g., $[52,53])$ where it is linked to Caledonian thrust movements [54]. Faults characterize the bedrock to many of the prominent gullies in the landscape along the western coast of the island, and a zone of mylonitized anorthosite occupies much of the central part of southern Iona (see Figure 1) [40]. A wide range of Proterozoic and Phanerozoic tectonic events may have influenced the gneiss complex, ranging in more recent geological times from thrusting at the margins of the Caledonian orogen to Paleogene North Atlantic rifting.

\section{Outcrop-Scale Observations}

This study focuses on a cluster of small low-lying exposures of dominantly metabasic amphibole-rich gneisses on the beach (see Figure 2(a)) at Camas Cuil an t-Saimh (The Bay at the Back of the Ocean-UK Ordnance Survey Grid Reference NM 2674 2371) on the Atlantic coast of Iona (see Figure 1). The rocks are immediately adjacent to exposures of mostly granitic gneiss to the west, and $\mathrm{cm}$ - to $\mathrm{dm}$-scale sheets of each "end member" occur within each dominant "host" (see Figures 2(c), 2(f), and 2(g)). The metabasic gneisses contain small $\mathrm{cm}$ - to $\mathrm{dm}$-scale feldspathic pegmatitic segregations that are generally aligned in a NE-SW orientation (see Figures 2(d) and 2(e)), consistent with the regional structural trends in the gneisses [40]. The extent of the exposures varies somewhat depending on the distribution of beach sand, with the main sampled block having a total length of $1.2 \mathrm{~m}$ when it was sampled in summer 2017 (see Figure 2(a)). The small elongate epidote-rich block towards the top of the view in Figure 2(a) is separated from the larger block by a sand-filled gully, which on excavation contains a quartz vein, epidote-rich gneiss, and a thin discontinuous trace of a reddened fine-grained fault rock (see Figure 2(b)). These exposures are representative of the general relationships shown by the orthogneisses over much of the western side of Iona. Both the amphibole-rich metabasic gneisses and the felsic granitic gneisses have a weak fabric but otherwise lack internal heterogeneity other than the extent of retrogression. Retrogression of the gneisses is most evident through the patchy but widespread development of epidote (see Figures 2(b)-2(h)). Two main types of epidotization are present:

(1) Particularly intense alteration has locally produced epidosites, which typically occur in cm-thick planar structures that cut the gneisses (see Figure 2(b))

(2) Local epidote replaces plagioclase within the metabasic gneisses. This retrogression typically has a patchy distribution but is pervasive when it does occur (see Figures 2(c) and 2(d)) 


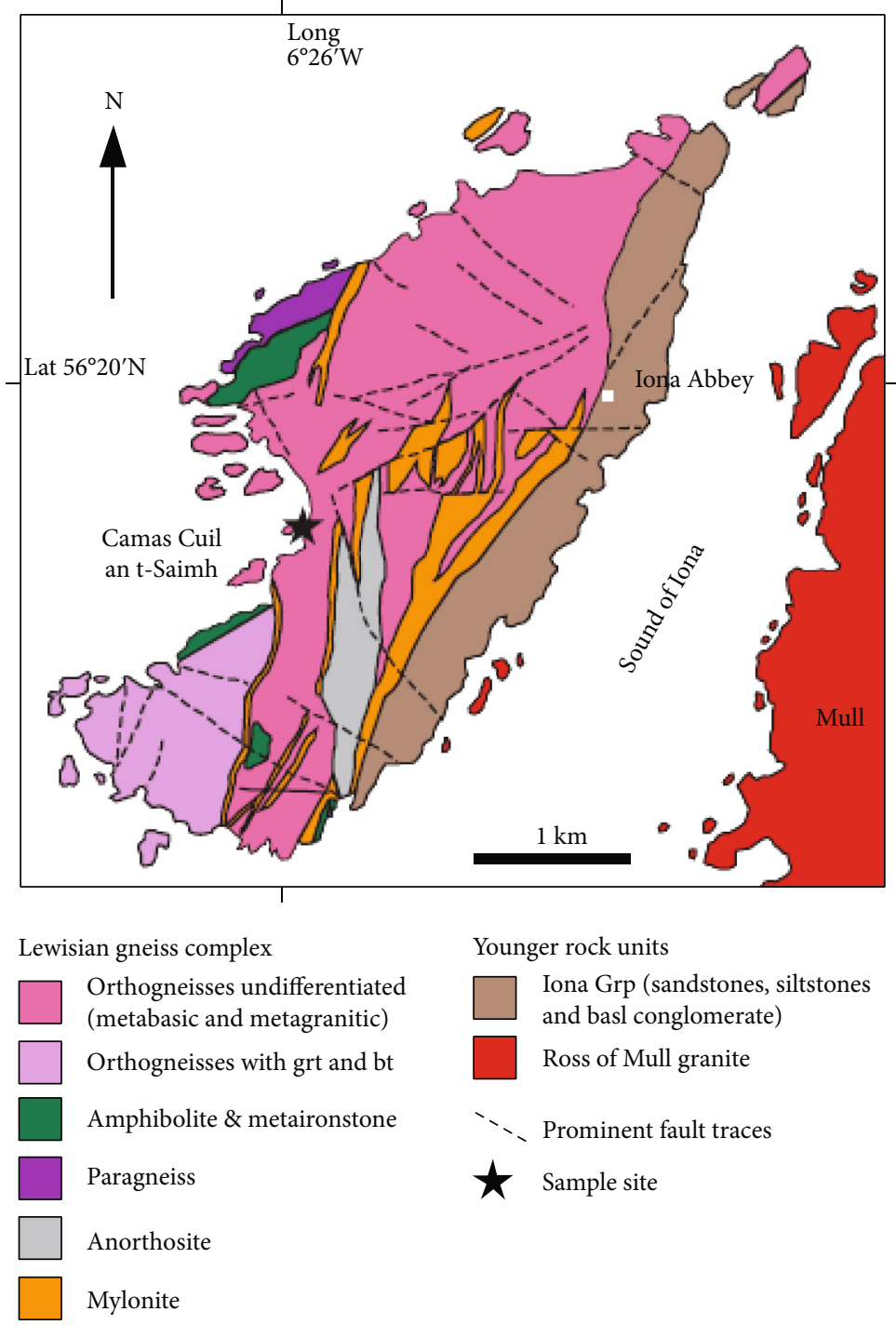

FIGURE 1: Summary geological map of Iona, showing main rock units based on BGS map and Fraser [40].

Although there is generally a positive correlation between the intensity of epidotization of the host gneisses and the number and size of epidosite-bearing fractures, there is a lack of systematic variation on a small scale such that unretrogressed gneiss may be present immediately adjacent to epidosite.

Clasts containing epidote-rich gneisses are reported in the basal conglomerate of the Iona group sediments [40]. Therefore, at least some of the epidotization is of likely Proterozoic age.

A variety of veins are present throughout the gneiss exposure. Generally, most larger fractures and veins have a NESW trend and a steep dip (see Figure 2(b)) (cf. [45]). A few fractures and veins dip at moderate angles towards the east. Larger zones of epidosite have a range of orientations, whilst small epidote-filled fractures are dominantly shallowly or moderately dipping towards the southeast. In thin sections, some of the cataclasites show evidence of minor displacements that indicate top-to-northwest reverse fault movements. Calcite- and quartz-filled veins lacking epidote have variable orientations but are typically more steeply dipping towards the north and northwest.

The granitic gneisses in the vicinity contain abundant pink K-feldspar and albite and also host a variety of epidote veins ranging from thin anastomosing structures to $\mathrm{cm}$ thick veins of epidosite with sharply defined margins (see Figure 2(f)). Epidote may be abundant at the margins of granitic gneiss, although there is typically limited alteration of feldspars to epidote away from these margins (see Figure $2(\mathrm{~g})$ ). In exposures of dominantly granitic gneisses to the southwest (NM 2654 2334), irregular-shaped, cmscale pseudotachylite veins are abundant containing angular fragments of the host gneisses (see Figure 2(h)). Such veins are of limited lateral extent and are commonly present along the west coast of Iona. They occur within zones of extensively fractured gneiss, contain small angular clasts of host gneiss, and range from pale green (see Figure $2(\mathrm{~h})$ ) to locally jet black glass. The pseudotachylite veins are frequently cut by later epidote veins that have sharply defined margins (see Figure 2(h)). 


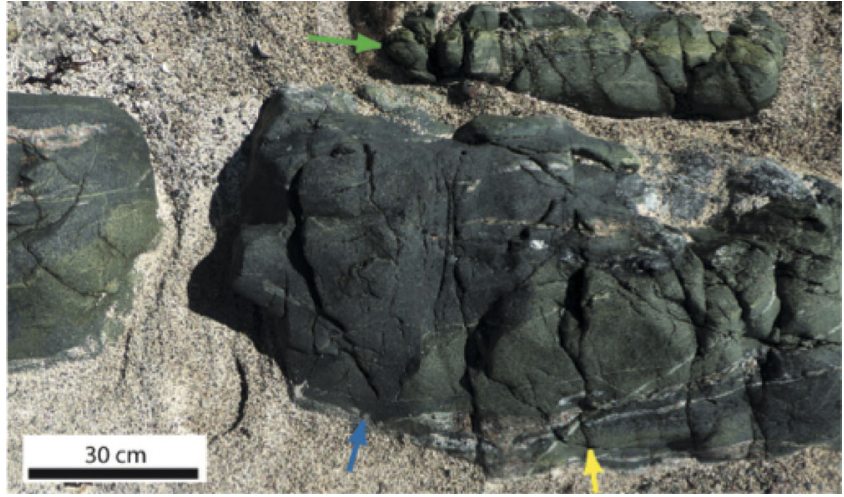

(a)

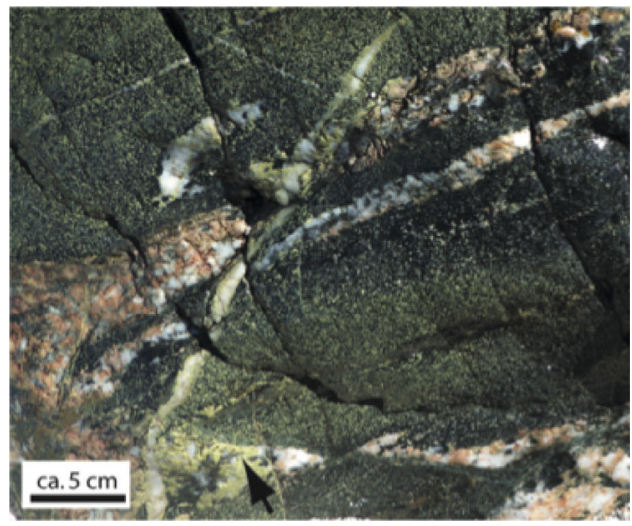

(d)

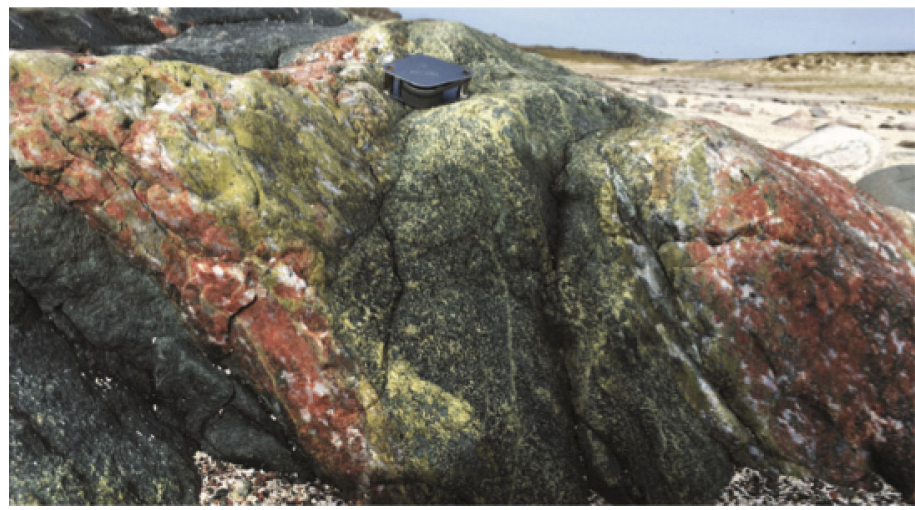

(g)

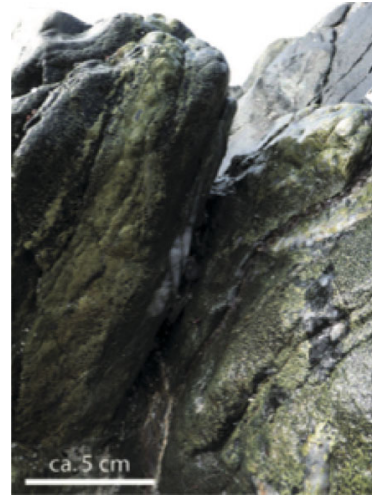

(b)

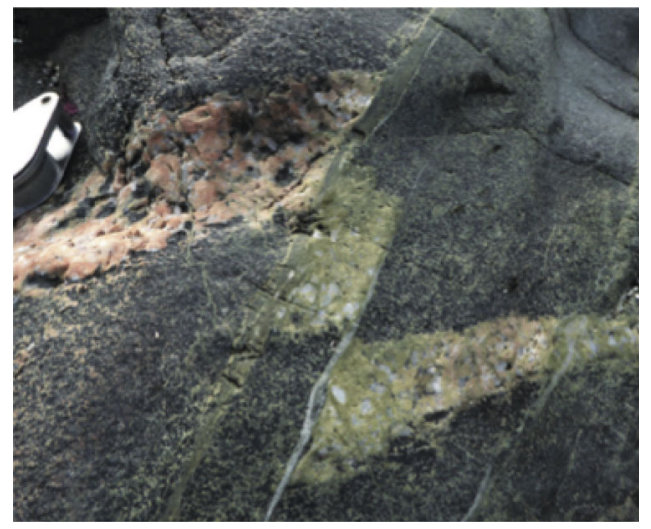

(e)

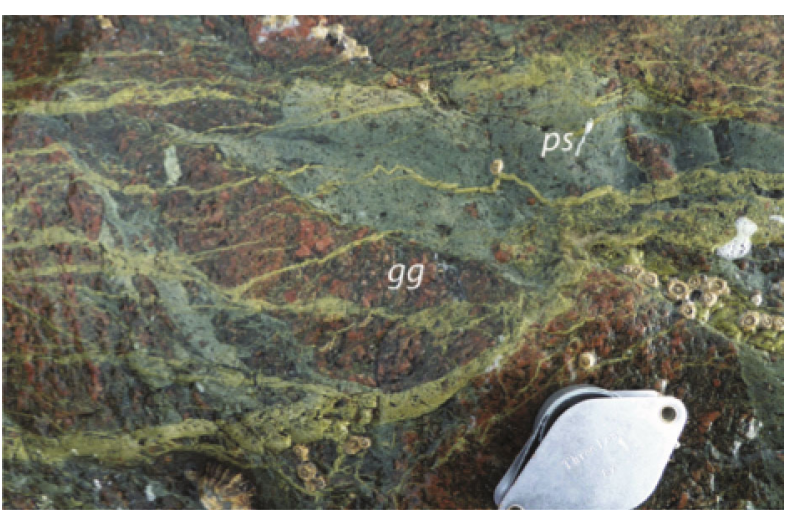

(h)

FIGURE 2: Field photographs of sampled exposures of gneisses. (a) Partially retrogressed metabasic gneiss blocks exposed in beach sand. Looking directly down on the exposure. Top of photograph represents a southeast direction. Elongate thin block towards the top of the view contains pale green $5 \mathrm{~cm}$ wide epidosite (marked by green arrow, shown in (b)). Blue arrow points towards the part of the exposure shown in (c); yellow arrow points to the view shown in (d). Positions of thin section samples F, G, H, and I are shown. Other thin sectioned samples are from adjacent blocks. (b) View of epidosite exposure looking towards the southwest with sand removed from the gully; (c) dark metabasic amphibole-rich gneisses with unmineralized (u) and mineralized (m) fractures, the latter is filled with pale green epidote and separates pervasively altered epidote-rich gneiss (eg) from relatively unaltered plagioclase-rich gneiss (pg); (d) metabasic gneiss with coarse pegmatite veins and hydrothermal veins filled with epidote and central zone of quartz. Gneiss in the central lower part of the view shows extensive alteration of plagioclase to green epidote and has an irregular boundary with the unaltered gneiss to the right of the view. Plagioclase in the pegmatite also locally shows extensive alteration to epidote (arrowed); (e) local alteration of feldspar-rich pegmatite to green epidote and associated epidote replacement of plagioclase in the host gneiss. Note the spatial restriction of alteration of the pegmatite by an epidote-filled cataclasite; (f) K-feldspar-bearing granitic gneiss with epidosite-filled fractures and limited pervasive retrogression of the host gneiss; $(\mathrm{g})$ sheets of metabasic and granitic gneiss showing pervasive epidotization of plagioclase in the former and more limited alteration of feldspars restricted to the margins of the granitic gneiss; (h) epidote veins within pseudotachylite (ps) and highly fractured granitic gneiss (gg) with no obvious marginal alteration of either host. Hand lens for scale. 


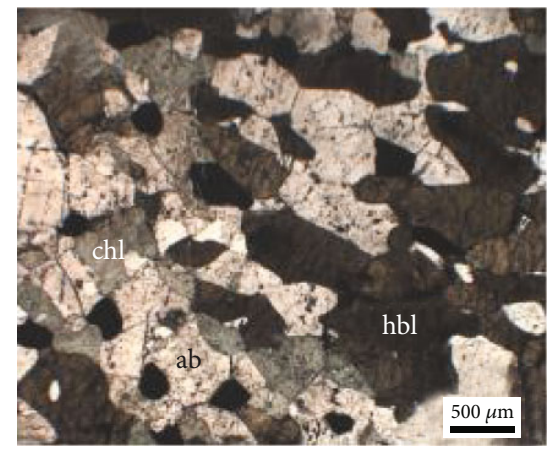

(a)

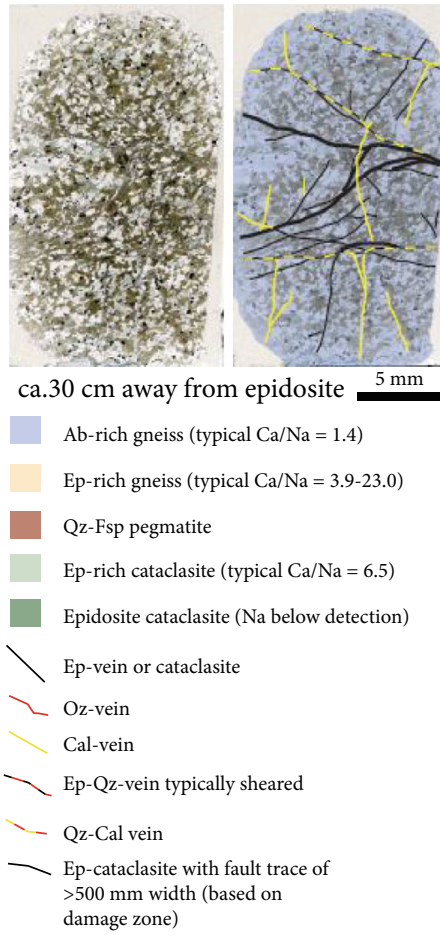

(b)

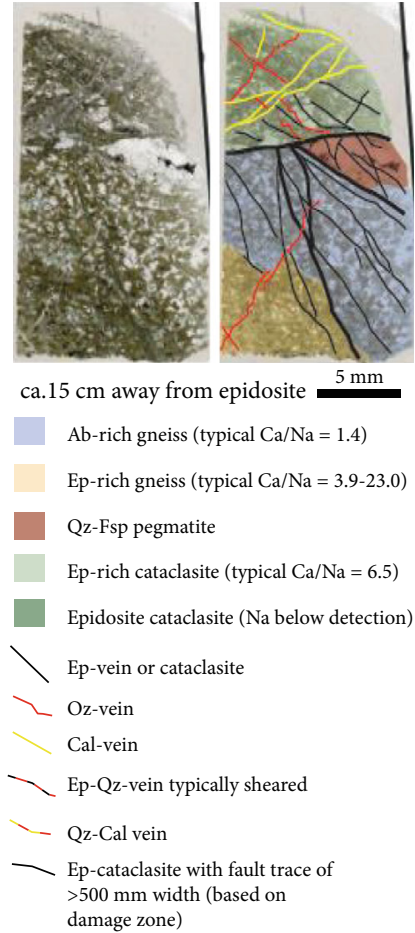

(c)

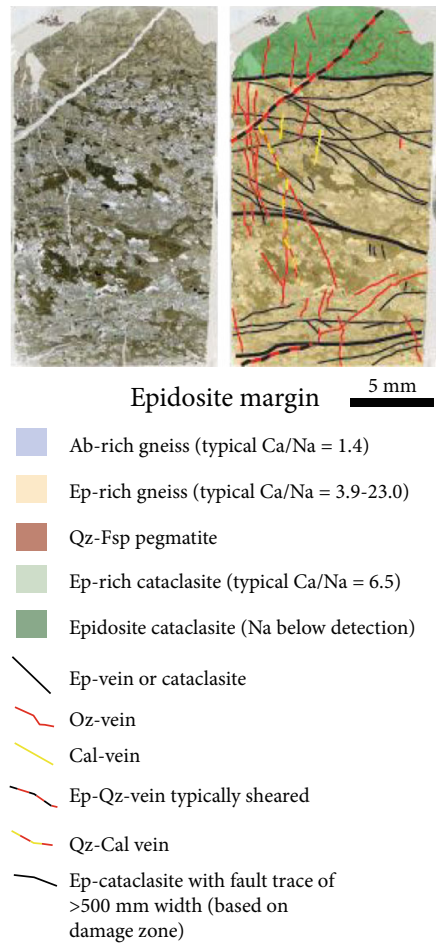

(d)

FIgURe 3: Photomicrographs of thin sections (plane polarized light: PPL). (a) Host metabasic gneiss with granoblastic texture, slightly elongate hornblende (hbl), albite (ab), and chlorite (chl) (abbreviations follow Whitney and Evans [95]); (b) thin section scan (sample G) (left view) and structural, lithological interpretation of texture (right view); (c) thin section scan (sample H) (left view) and structural, lithological interpretation of texture (right view); (d) thin section scan (sample I) (left view) and structural, lithological interpretation of texture (right view). The legend shows the ratio of elemental wt $\% \mathrm{Ca} / \mathrm{Na}$ determined by energy dispersive spectrometry.

\section{Methods}

Most samples were collected from a range of structural positions within the exposure shown in Figure 2(a); a few were from other low-lying blocks in the immediate vicinity both from metabasic and granitic gneisses, within a maximum distance of $10 \mathrm{~m}$ from the main sampled block. Polished thin sections (e.g., Figures 3(b)-3(d)) were cut perpendicular to the main fracture and vein orientations within each specimen and were used for petrographic descriptions. Grain boundary characteristics were assessed using snapped $5 \mathrm{~mm}$ thick slices, following methods described by Lawther and Dempster [55]. Samples were analysed by both secondary and backscattered electron imaging using the Quanta 200F field emission environmental scanning electron microscope at the University of Glasgow. X-ray mapping of polished thin sections using EDX emission spectroscopy processed using AZTEC Software 3.0 was used to assess both mineral compositions and spatial variations in bulk rock chemistry that correlate with the alteration processes. Although this semiquantitative approach results in some uncertainty in absolute mineral compositions, this neither materially influences the identification of effective mineral reactions from textural analysis or the first order volume changes associated with these reactions. Compositions from multiple line traverses $(n=44)$ each parallel to fracture orientation of ca. $15 \mathrm{~mm}$ length with $30 \mu \mathrm{m}$ spacing of 200 individual analysis spots were acquired from across X-ray maps perpendicular to the 


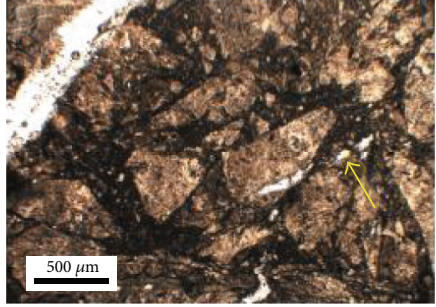

(a)

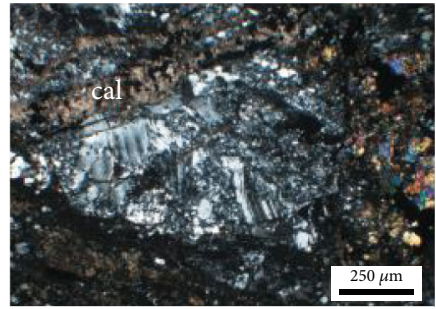

(d)

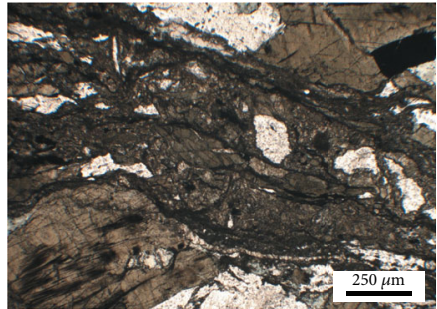

(b)

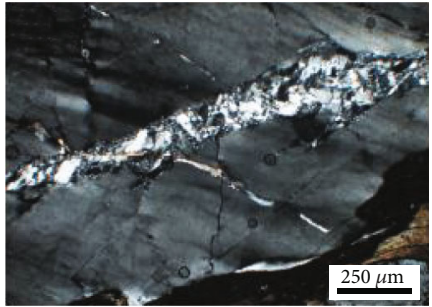

(e)

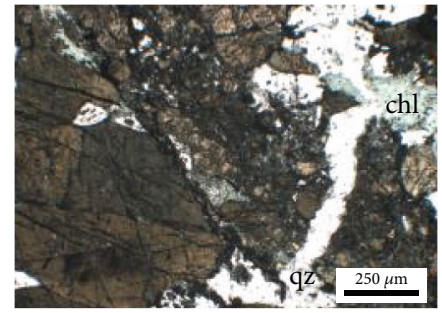

(c)

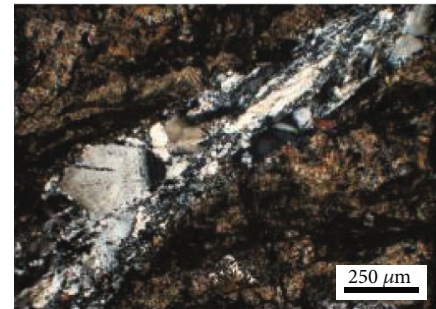

(f)

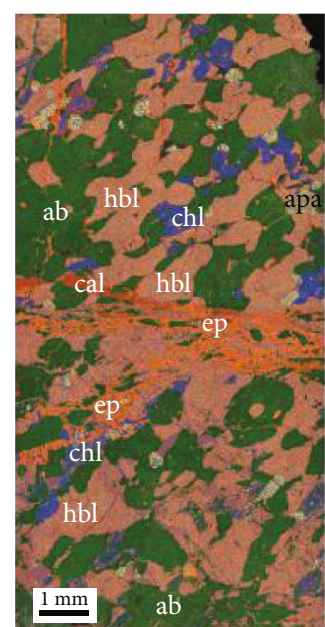

(g)

FIgURE 4: Photomicrographs of fracture systems. (a) Brecciated texture of epidosite cataclasite (thin section I), with mylonitized quartz-filled vein (top left) and fragments of mylonitized quartz-filled vein (arrowed) within individual clasts of epidosite in a fine-grained epidote matrix (PPL); (b) cataclasite composed of clasts of amphibole in an epidote-rich matrix (thin section G) (PPL); (c) cataclasite of amphibole gneiss, cut by quartz- (qz-) and chlorite- (chl-) filled vein (thin section H) (PPL); (d) large highly deformed clast containing brecciated quartz and albite within epidote-rich altered cataclasite (thin section $\mathrm{H}$ ). Calcite-bearing vein (cal) towards the top of the view (crossed polarized light: XPL); (e) thin band of quartz mylonite within large quartz grain in pegmatite. Original quartz shows extensive subgrain development (thin section F) (XPL); (f) mylonite texture in quartz vein that cuts the epidosite pictured in (a) (thin section I) (XPL); (g) X-ray distribution map showing $\mathrm{Ca}$ - (orange), Na- (green), and Mg- (blue) part of thin section $\mathrm{G}$, with central epidote-bearing (intense orange) cataclasite containing small relict clasts of albite (green) and amphibole (pink). Calcite veins show as red (thin section G).

main fracture orientation. An average composition for each individual traverse was obtained to assess small-scale geochemical variation in relation to fracture location. Average compositions associated with individual traverses show some variation that is linked to the large grain size of the host gneiss, but chemical differences identified on either side of the fracture are not influenced as effective grain size of each portion of the rock is identical on either side of the fracture. Whole rock compositional data are determined from EDS $\mathrm{X}$-ray mapping of large $\mathrm{mm}^{2}$ areas of representative gneiss types. Whole rock compositions of largely unretrogressed Lewisian basic gneisss used for comparative purposes are from both Iona [40] and elsewhere in the Lewisian gneiss outcrop [56]. Note the close match between our estimated compositions and Iona rock compositions measured by Fraser [40].

\section{Results}

5.1. Host Gneiss Petrography. The metabasic host gneisses are composed of $0.5-1 \mathrm{~mm}$ dark green hornblende (ca. $35 \mathrm{vol} \%$ ) and clear or partly sericitized albite (ca. $40 \mathrm{vol} \%$ ) in a granoblastic texture, with small amounts of Fe-oxides (see Figure 3(a)) and local quartz. Apatite and zircon are present in trace concentrations. The metabasic gneisses show a weak mineral alignment with a general NE-SW strike defined by the shape of the amphiboles (see Figure 3(a)). The remainder of the gneiss is composed of retrograde hydrothermal greenschist-facies minerals. Chlorite is abundant (up to 20 vol\%), although its distribution may be somewhat patchy within an individual sample. The chlorite typically forms as fine-grained $(<50 \mu \mathrm{m})$ aggregates in a pseudomorphic replacement of an earlier phase with a coarse-grained granoblastic texture (see Figure 3(a)). Individual chlorites within these aggregates tend to show a weak alignment, but this alignment varies between each aggregate. Elsewhere on Iona, metabasic gneisses that have experienced less retrogression contain oligoclase or andesine and hornblende, together with orthopyroxene and/or clinopyroxene; local garnet may also be present [40]. Rare relict orthopyroxene is present in our samples. The weak alignment of chlorite within each pseudomorph may be a relict of an original cleavage within the pyroxene host.

The nearby granitic gneisses contain coarse-grained coarsely perthitic K-feldspar, albite, quartz, and up to $10 \%$ amphibole. They also show extensive retrogression, although epidotization is limited away from discrete fractures (see Figures 2(f) and 2(g)).

5.2. Fault Rock Types, Distribution, and Mineralization. A variety of mineralized or unmineralized fracture types are present (see Figures 2(b)-2(h)). Fault rocks, mostly cataclasite, may be subsequently mineralized (see Figure 4(g)), and these together with the veins that contain evidence of significant shear displacement are described in this section. The mineralized fault rocks are distinguished from veins by relict clasts of host rocks (see Figure 5). A range of fault rocks occur within the gneisses, including abundant cataclasite and rarer mylonite (see Figure 4). The former commonly lacks abundant plagioclase and has a matrix dominated by epidote and fine-grained amphibole (see Figures 4(b) and 4(c)). 


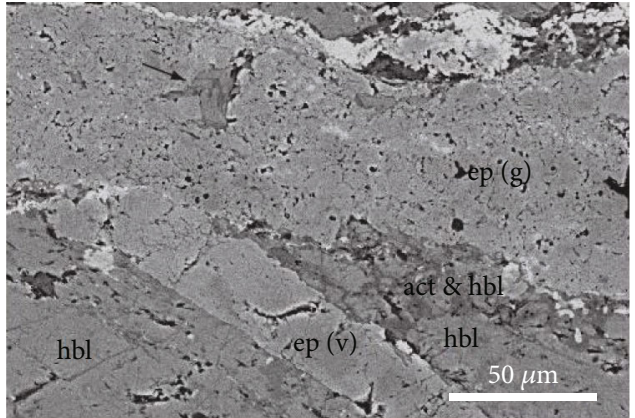

FIGURE 5: Backscattered electron image of epidote vein $(\mathrm{ep}(\mathrm{v}))$ cut by granular epidote cataclasite seam $(\mathrm{ep}(\mathrm{g}))$. Large amphibole (hbl) in host gneiss cut by hornblende- (hbl-) actinolite (act) cataclasite, relict clasts (arrowed) of which appear within the granular epidote seam.

Many of the small faults show evidence of shear displacement that is typically less than a few $100 \mu \mathrm{m}$, even where mylonite is present along the fracture trace.

Cataclasite-bearing fractures (see Figures 3(b)-3(d)) are typically most numerous in close proximity to the prominent epidosite (see Figure 3(d)) in the southeast of the main exposures (see Figure 2(a)). The epidosite is predominantly composed of large $\mathrm{mm}$-scale angular clasts of epidosite, containing coarse-grained (typically $50 \mu \mathrm{m}$ but up to $500 \mu \mathrm{m}$ ) granular epidote, in a finer-grained matrix of relatively $\mathrm{Fe}-$ poor epidote cataclasite (see Figure $4(\mathrm{a})$ ) with minor $<5 \%$ quartz and actinolite.

Hornblende is locally brecciated along unmineralized fault traces and also occurs as isolated relicts along fractures that are dominated by epidote mineralization (see Figures 4(b), 4(c), and 4(g)). In the latter, irregular-shaped clasts of amphibole-rich cataclasite typically have thin (5$10 \mu \mathrm{m}$ ) actinolite rims and occur in a matrix of fine-grained actinolite and abundant epidote (see Figure 5). The epidote may be zoned with a relatively Fe-rich, Al-poor rim. The hornblende clasts are typically $<100 \mu \mathrm{m}$ long and may show evidence of a weak alignment. The amphibole-dominated fault rocks typically occur in fractures of ca. 200-300 $\mu \mathrm{m}$ width, but bands of fine-grained cataclasite of more than $1 \mathrm{~mm}$ width are also present (see Figures 3(b)-3(d)).

In host gneisses that have experienced more extensive cataclasis, the microtextures may be obscured by later partial to near-complete alteration to epidote. Such areas form planar zones, and near their margins may contain relatively unaltered angular clasts (up to $1 \mathrm{~mm}$ ) of highly deformed quartz and feldspar protocataclasite (see Figure 4(d)) between thin anastomosing planes of fine-grained chloriteand epidote-rich matrix. Some alignment of elongate quartzofeldspathic clasts and amphiboles is typically present parallel to the margins of such zones (see Figure 4(g)). The zones of intense cataclasis lack abundant hornblende and are characterized by high $\mathrm{Ca} / \mathrm{Na}$ (see Figure 3(c)), reflecting the abundance of epidote.

Evidence of mylonitization is present within some of the quartz-rich pegmatitic segregations, with numerous thin trails of fine-grained (10-20 $\mu \mathrm{m})$ quartz mylonite along shear surfaces (see Figure 4(e)). Cataclasis of adjacent gneisses is locally intense around the margins of pegmatitic segregations producing fine-grained hornblende- and epidote-rich cataclasites (see Figure 3(c)). Some of the quartz-epidote-filled veins have also been mylonitized, where the quartz in the central part of the fill is aligned in protomylonites subparallel to the fracture margins (see Figure $4(\mathrm{f})$ ). Such veins typically have coarse euhedral epidote at their margin (see Figure 6(b)). Mylonitized quartz-filled veins occur in the epidosites, and the fragments of these mylonitized veins are also present within some individual clasts of epidosite cataclasite (see Figure 4(a)).

5.3. Nature and Relative Timing of Veins. Two main types of veins crosscut the gneisses. One group is dominated by epidote (see Figures 2(d), 2(f), 2(h), 3(b)-3(d), 5, and 6(a)) but may locally contain quartz (see Figure 6(b)) and minor pyrite. This group may show evidence of internal shear (described in the previous section), especially those containing quartz, but typically lack evidence of deformation. The epidote-filled veins range in width from a few mm (see Figures 2(d), 2(f), and 2(h)) to less than $50 \mu \mathrm{m}$ and are distinguished from the epidote-rich structures described in the previous section because they lack cataclastic relicts and replacement textures. Epidote veins both cut and are cut by epidote-rich cataclasites (see Figure 5). Many of the epidote veins are composed of granular epidote that is coarse-grained (up to $300 \mu \mathrm{m}$ ) in the thicker veins (see Figures 5 and 6(a)).

A set of later veins (see Figures 3 and 6(c)) is dominated by either calcite or quartz but locally associated with actinolite, chlorite, and Fe-oxides (see Figures 6(d)-6(f)). They occur at a high angle to those with an epidote fill (see Figures 3(b)-3(d)), have a more irregular trace, and typically lack evidence of shear displacement and cataclasis. Some of these veins form in an en echelon geometry. In rare instances, calcite shows evidence of limited shear with curvature of cleavage traces and twin planes. The calcite-quartz veins are up to ca. $0.5 \mathrm{~mm}$ wide, but more typically less than $100 \mu \mathrm{m}$. Calcite veins typically cut cataclasites (see Figure 3 ) and are often associated with small amounts of disseminated $\mathrm{Fe}$ oxide. Quartz veins are rare in samples where there is very limited epidote present (see Figure 3(b)). This group of veins has a complex mineralogy, and the nature of the mineral fill depends on the local mineralogy of the host gneiss (see Figures $6(\mathrm{~d})-6(\mathrm{~g}))$. This variability occurs on the scale of the grain size of the host gneiss (i.e., $0.5-1 \mathrm{~mm}$ ). Individual veins commonly contain calcite and quartz, but single veins may transform from one fill type to the other (see Figures $6(\mathrm{~d})-6(\mathrm{~g}))$. Calcite fill is present where the vein cuts hornblende in the host gneiss (see Figures 6(d) and 6(g)), whereas quartz fill is present where the vein cuts quartz or albite in the gneiss (see Figures 6(d) and 6(g)). Locally calcite fill also occurs adjacent to epidote in the wall rock. Fibrous fine-grained actinolite margins to veins are also present where adjacent to hornblende in the wall rock (see Figures 6(d) and $6(\mathrm{~g}))$. In cases where this complex and variable vein fill is present, calcite typically forms in the central parts of the vein (see Figure 6(e)). Chlorite occurs locally in these veins where the wall rock contains Fe-oxide (see Figures 6(d) and 6(e)). 


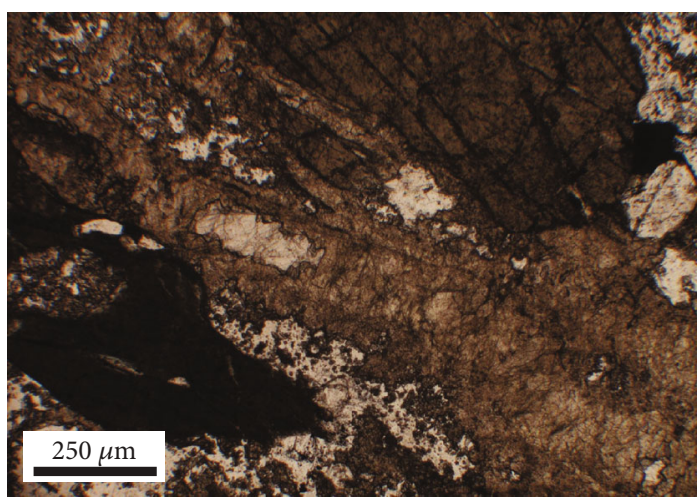

(a)

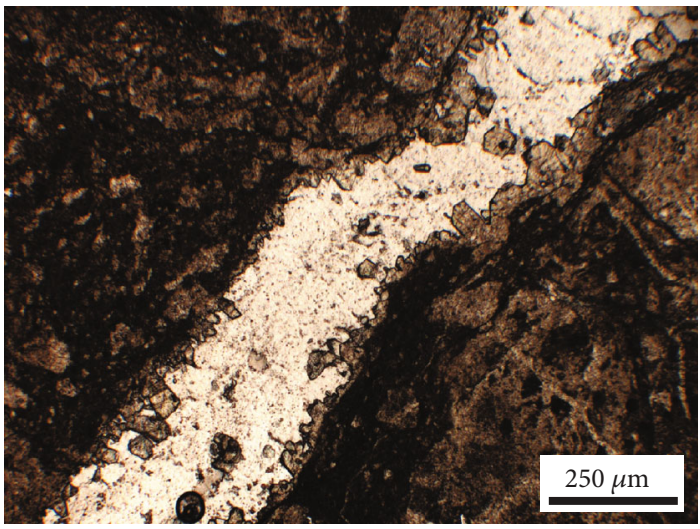

(b)

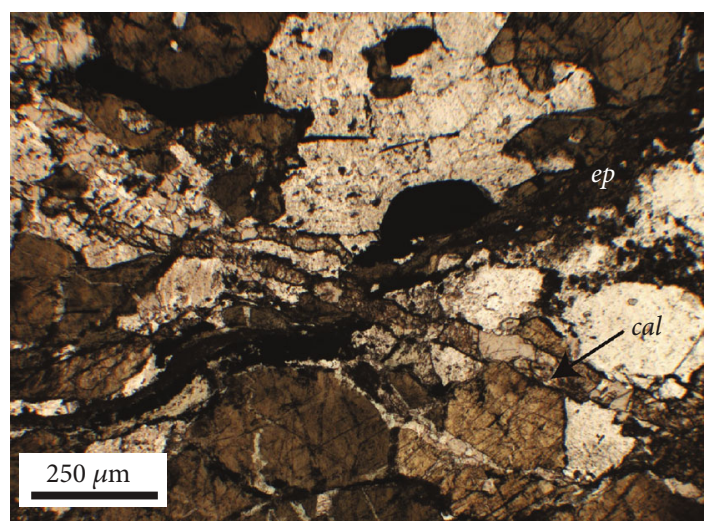

(c)

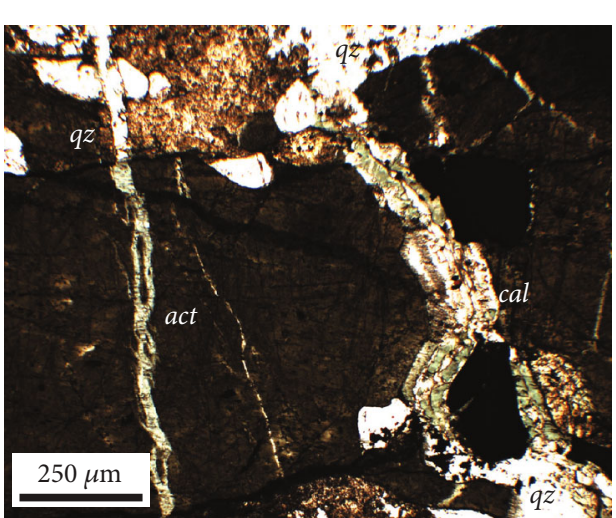

(d)

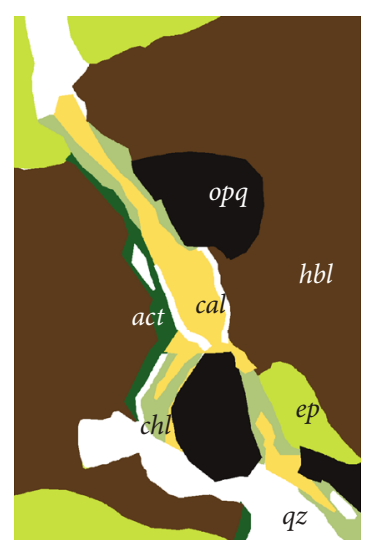

(e)

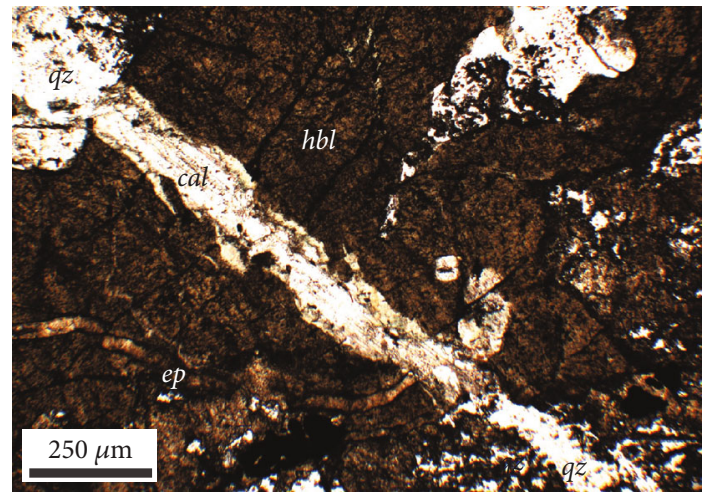

(f)

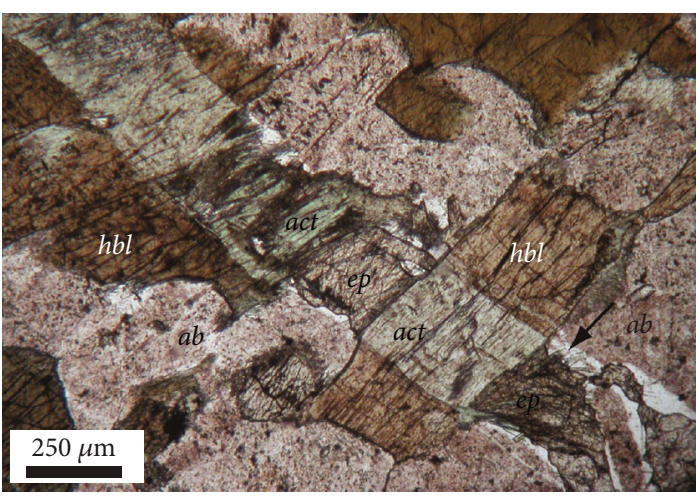

(g)

Figure 6: Photomicrographs of veins. (a) Coarse-grained epidote vein, with central area containing quartz with actinolite needles, cutting across hornblende in altered gneiss (thin section I) (PPL); (b) quartz and epidote-filled vein cutting across epidosite. Marginal epidote shows euhedral shapes (thin section I) (PPL). Quartz has mylonite texture shown in Figure 4(f); (c) calcite-filled vein crosscutting thin epidote-bearing sheared vein (thin section G) (PPL); (d) complex fill of quartz-filled veins as they cut through a hornblende in the host altered gneiss (thin section I) (PPL). Vein on left shows quartz-fill cutting through epidote (top of view) and actinolite-fill, in optical continuity with the host hornblende, where the vein cuts the amphibole host. The vein on the right has quartz-fill at top and base of view where it cuts epidote and quartz in the wall rock and calcite-chlorite-actinolite-fill where it cuts through wall rock hornblende; (e) cartoon showing summary of mineral textures for the thick vein shown in (d); (f) quartz-filled vein transforming into calcite-filled vein with marginal actinolite, where it cuts hornblende in the host gneiss. Note thin epidote vein cuts across hornblende host (thin section I) (PPL); (g) actinolite- and epidote-filled fracture in the sample of gneiss from the southwest of Iona collected by Fiona Fraser (Sample F464, in Hunterian museum collection (Entry 666), Grid Ref NM253 221) showing variation in fracture fill controlled by the mineralogy of the adjoining host. The arrow shows clear albite at the edge of the vein with epidote fill.

5.4. Nature, Distribution, and Geochemistry of Pervasive Alteration. Greenschist-facies alteration of the host gneiss may be spatially constrained by cataclasites and/or localized adjacent to veins (see Figures 2(c) and 7(a)). In other instances, it is more pervasive and apparently unrelated to the distribution of veins or cataclasites (see Figure 2(d)). 


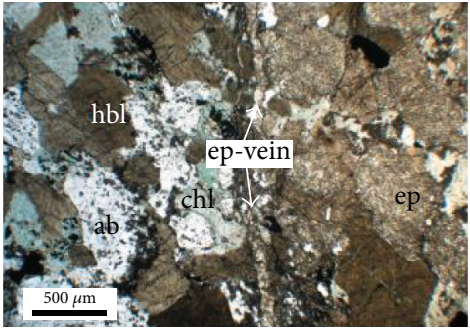

(a)

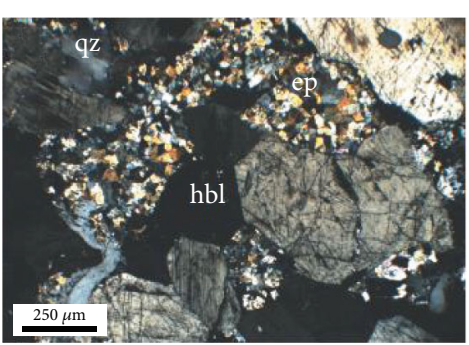

(b)

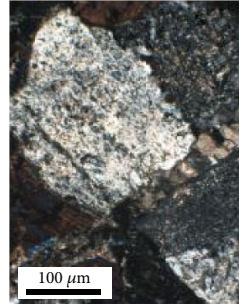

(c)

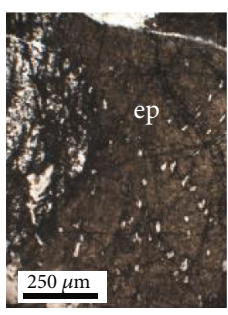

(f)

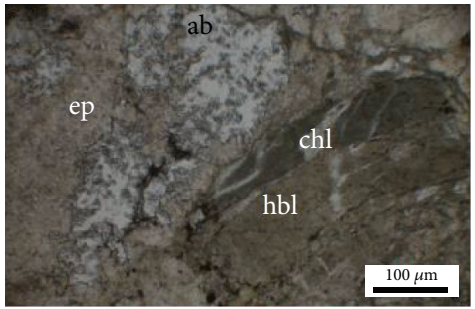

(d)

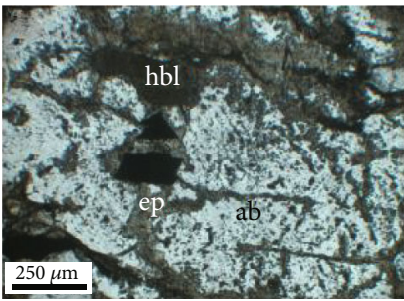

(g)

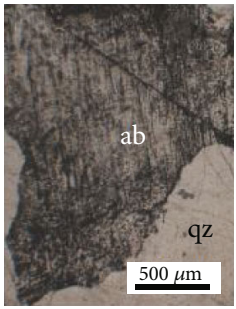

(e)

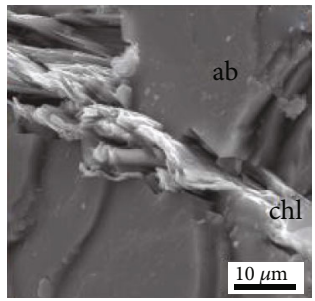

(h)

FIGURE 7: Photomicrographs of pervasive alteration textures in the gneiss. (a) Epidote vein marking sharply defined boundary between plagioclase (albite)-rich gneiss to the left and epidote-rich gneiss to the right (thin section I3) (PPL); (b) granular textured epidote replacement texture within granoblastic gneiss (thin section AH1) (XPL); (c) sericitization of plagioclase (thin section S) (XPL); (d) marginal alteration of albite to epidote along minor fractures and grain boundaries at margins of epidosite (thin section I) (PPL); (e) alteration of coarse-grained albite plagioclase within pegmatite to fine-grained epidote along feldspar twin planes (thin section F) (PPL); (f) complete alteration of coarse-grained plagioclase at the margin of pegmatite to a combination of fine-grained epidote and small elongate quartz "blebs" (thin section F). Adjacent albite has cataclastic texture (PPL); (g) relict plagioclase within epidote gneiss and large deformed hornblende with minor marginal alteration to chlorite (thin section I) (PPL); (h) secondary electron image of plagioclase grain boundary with thin sheets of chlorite coating the boundary (sample AH1).

There is no correlation of the spatial distribution of retrograde reaction products with any preexisting features of the original host gneisses, which other than amphibole alignment are texturally and mineralogically homogeneous. Overall proximity to the larger epidosites broadly correlates with the degree of epidote alteration of the host metabasic gneiss (see Figure 3(d)).

Plagioclase in the metabasic gneiss and also within the felsic pegmatite segregations has a consistent albite composition. It may show minor sericitization (see Figure 7(c)), with small amounts of disseminated calcite. Subsequent alteration of albite is dominated by a partial or more commonly complete replacement by epidote (see Figures $7(\mathrm{a})$ and $7(\mathrm{~b})$ ) and an associated increase in the $\mathrm{Ca} / \mathrm{Na}$ ratio of the rock (see Figure 3). The epidote has $X_{\mathrm{Fe}}$ of ca. 0.3 typical of many greenschist-facies compositions in metabasic lithologies [57]. The replacement initially occurs along either grain boundaries or twin planes, the latter producing regular-spaced, parallel-aligned arrays of fine-grained granular epidote within the albite (see Figure 7(e)). Although in some instances all retrograde products occur in close proximity (see Figure 6(d)), more typically complete replacement of albite produces granular aggregates of epidote $(30-50 \mu \mathrm{m})$ in an overall granoblastic texture with hornblende and chlorite (see Figure 7(b)). Transitional contacts between epidoteand albite-bearing gneiss are present, but in most instances, these contacts are extremely sharp and often marked by the presence of a thin vein of granular epidote (see Figures 2(c) and $7(a))$. Epidotization may be extremely patchy where numerous cataclasites transect the host gneiss, but in general, there is less alteration of albite where there are more thin epidote-bearing veins and cataclasites in the immediate vicinity (see Figure 3(c)). Albite in granitic gneiss has less alteration to epidote than those feldspars in adjacent metabasic gneiss (see Figure $2(\mathrm{~g})$ ).

In some examples, where extensive alteration of albite to epidote has occurred, small ca. $50 \mu \mathrm{m}$, oval-shaped "blebs" of quartz are evenly dispersed throughout the epidote aggregates (see Figure 7(f)). In the feldspathic pegmatites, epidote alteration may be extensive producing an assemblage 


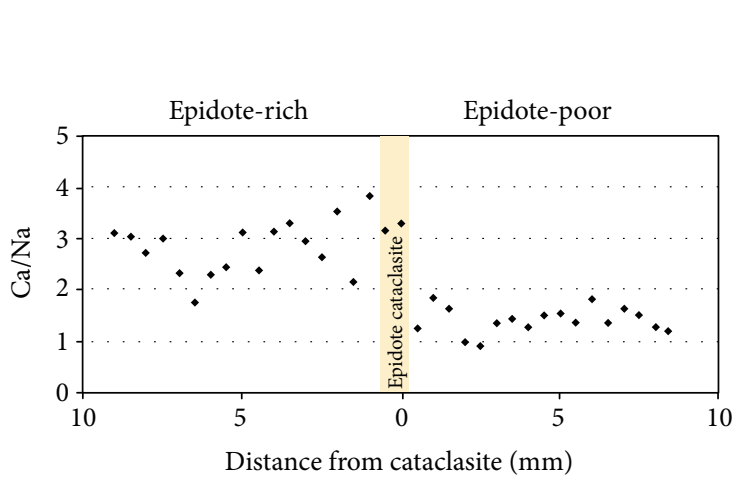

(a)

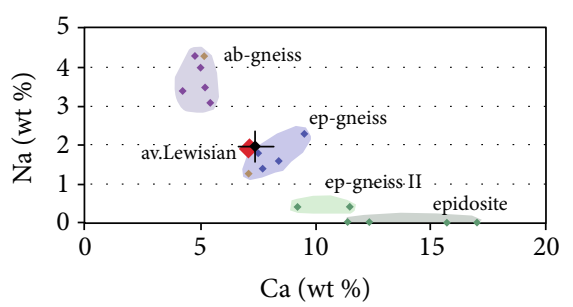

(c)

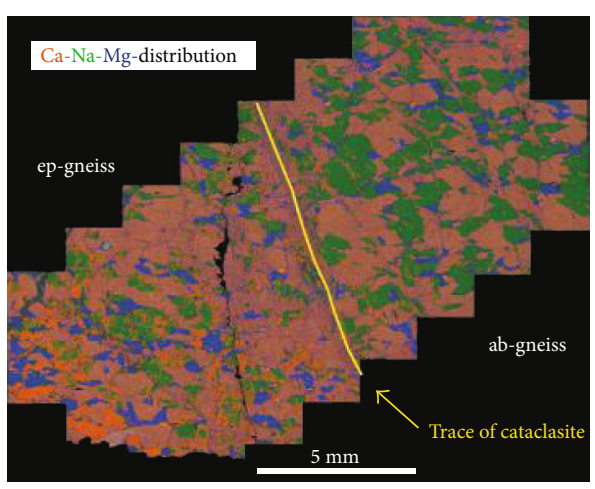

(b)

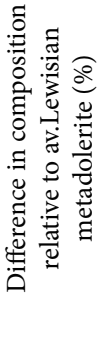

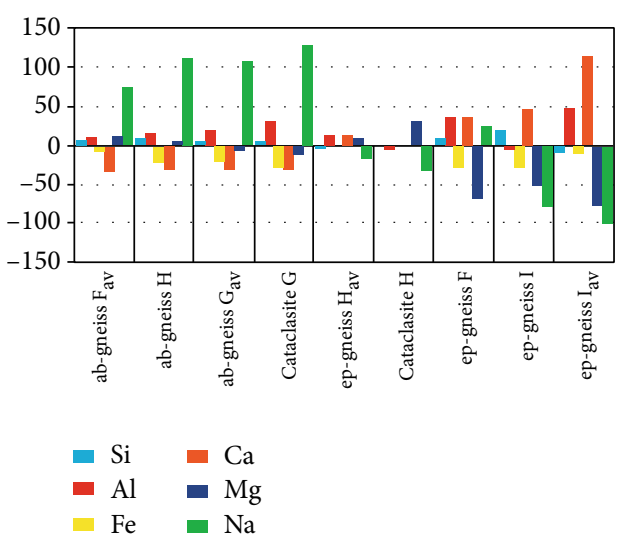

(d)

Figure 8: (a) Traverse showing $\mathrm{Ca} / \mathrm{Na}$ ratio of the metabasic gneiss on either side of an epidote-bearing cataclasite (thin section $\mathrm{H}$ ). Position of large fracture containing hornblende-epidote cataclasite marks the boundary between plagioclase (albite) gneiss to the right and epidote gneiss to the left; (b) X-ray distribution map showing Ca distribution in orange-red shades, Na distribution shown in dark green shades, and $\mathrm{Mg}$ distribution shown in blue (thin section $\mathrm{H}$ ). Note the fracture trace itself has a similar composition to the epidote gneiss; (c) plot showing $\mathrm{Na}$ and $\mathrm{Ca}$ contents of different whole rock compositions of the gneisses relative to average metabasic gneiss (large red diamond) in the Lewisian [56] and metabasic gneisses lacking evidence of retrogression from Iona (black diamond with standard deviations represented by error bars, based on 16 samples) [40]. Cataclasite compositions within both albite- and epidote-gneisses are shown by orange diamonds. Epidote gneiss II represents gneiss composition immediately adjacent to epidosites; (d) comparison of major element chemistry of different retrogressed samples of metabasic gneisses with average Lewisian metabasic gneiss [56]. Values above the line represent enrichments; those below the line represent depletions.

dominated by epidote and coarse quartz (see Figure 2(e)). The extent of replacement of albite by epidote within the gneiss is matched by the $\mathrm{Ca} / \mathrm{Na}$ ratio of the whole rock (see Figure 8). This ratio broadly correlates with both the intensity and style of fracturing. Relative to the major element compositions of unretrogressed metabasic gneisses [40], the retrogressed gneisses show the most marked difference in their relative $\mathrm{Na}$ and $\mathrm{Ca}$ contents (see Figure 8(d)). Albitebearing gneisses lacking significant epidote show relative enrichment in $\mathrm{Na}$ (see Figures 8(c) and 8(d)). Epidosites and those gneisses immediately adjacent to the thicker epidosites are strongly enriched in $\mathrm{Ca}$ and depleted in both $\mathrm{Na}$ and $\mathrm{Mg}$ (see Figure 8(d)). The overall major element composition of the epidote-rich gneisses is broadly similar to typical Lewisian metadolerites [56] and unretrogressed metabasic gneisses from Iona [40] (see Figures 8(c) and 8(d)). Cataclasites in albite-rich gneiss and epidote-rich gneiss have compositions that are similar to the adjacent host (see Figure $8(c)$ ).
Hornblende tends to show the least evidence of retrogression apart from local thin altered zones of either chlorite (see Figure $7(d)$ ) or actinolite immediately adjacent to some veins (see Figure 6(e)) or around relict clasts in cataclasites (see Figure $7(\mathrm{~d})$ ). Even in rocks showing complete replacement of albite by epidote, granoblastic hornblende persists largely unaltered (see Figure $7(\mathrm{~b})$ ). Within the zones of epidosite, rare irregular fragments of largely unmodified hornblende are also present and small needles of actinolite are widely dispersed.

Several generations of chlorite are present, although granoblastic aggregates of chlorite are most common. Minor chlorite occurs in the vein assemblage and as a local marginal replacement of hornblende (see Figure $7(\mathrm{~d})$ ). Chlorite typically forms in proximity to small amounts of Fe-oxide. Grain boundaries of the granoblastic textured host minerals are typically characterized by thin $5-10 \mu \mathrm{m}$ coatings of chlorite (see Figure $7(\mathrm{~h})$ ). These are less obvious where the albite 


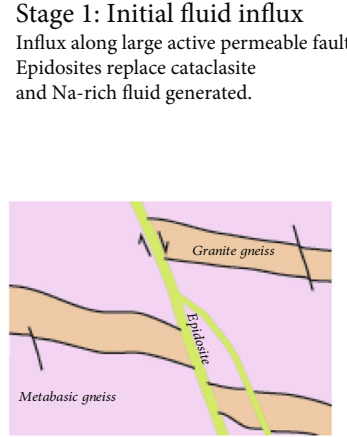

Stage 2: Na-rich fluid migrates Fluid overpressure causes fluid to migrate into host gneisses along "open" grain boundary network.

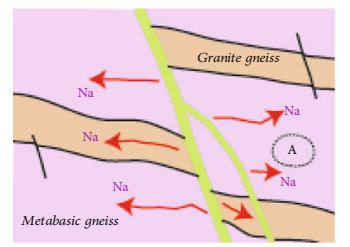

Area A: influx of Na-rich fluid from nearb large epidosite-bearing fault

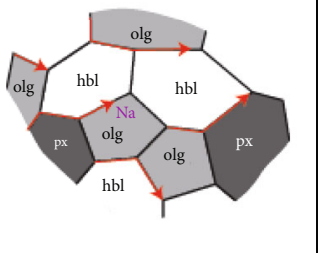

Stage 3: Reactivation \& fluids drawn back to fault Pervasive retrogression produces ab and ch and Ca-rich fluid. Fault reactivation (cause cataclasis of epidosite) and volume change linked to ep replacement of ab draws fluid towards local reaction sites and fractures.

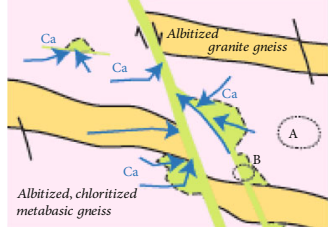

Area A: Ab replaces Olg all gneisses, Ch replaces $P x$ coats grain boundaries and restricts permeability in metabasic gneisses. Ca-rich fluid produced and migrates to evolving high porosity areas $($ Area $B)$

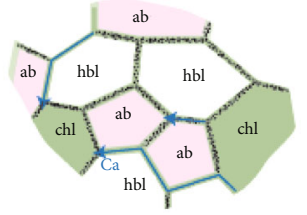

Stage 4: Cycle repeats

Na-rich fluids produced and migrate into host gneisses during interseismic periods. Ca-rich fluids drawn back towards fault zones and epidote reaction sites in coseismic events.
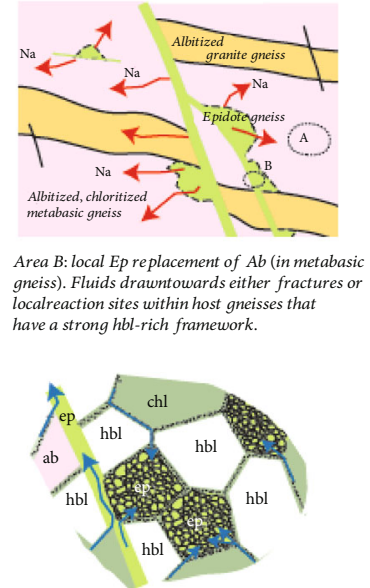

FIGURE 9: Model showing the progressive changes in fluid infiltration history in fractured metabasic and granitic gneisses. Schematic representation of mineral reaction history shown in lower sketches for two areas (A and B) in metabasic gneiss.

has been largely replaced by epidote, but thin sheets of chlorite may still be present between clusters of epidote grains, possibly marking the positions of former grain boundaries within the host.

5.5. Chronology of Events. A summary of the probable sequence of key metamorphic and structural events is presented below. This relative history is based on the textural criteria in the field and thin section analysis presented above.

(i) Peak metamorphic amphibolite- or hornblende granulite-facies gneiss

(ii) Pseudotachylite formation (uncertain age but predates many epidote-filled veins)

(iii) Large planar brittle cataclasites generated during shearing (possible localized epidotization and minor quartz along these fractures)

(iv) Widespread alteration of Ca-bearing plagioclase to albite and pyroxene to chlorite in the host gneisses (overall loss of $\mathrm{Ca}$ )

(v) Cycles of cataclasis, epidote (with minor quartz) veining, and epidote replacement of cataclasite. Locally pervasive alteration of albite to epidote in the host gneisses (overall gain of $\mathrm{Ca}$ ). Further brittle failure focused along epidote-bearing faults

(vi) Calcite-quartz veins cut epidote-bearing fractures

\section{Interpretation}

6.1. Retrograde Reactions. A complex history of fluid infiltration is apparent from the retrograde reaction history of the gneisses. Although many veins in metamorphic terranes may form through segregation processes ( $c f .[23,58,59]$ ), those in the gneisses from Iona are filled with hydrous phases and crosscut a range of lithologies that lack the mineralogy of the vein fill (see Figure 6(e)). Consequently, most of the veins are thought to represent fluid conduits.

The retrograde history is dominated by pseudomorphic replacement of the high-grade mineralogy that allows individual reactions to be readily identified. The overall retrograde change produces a greenschist-facies assemblage in the original gneisses and suggests a hydration reaction of the type:

$$
\begin{aligned}
& \text { olg + opx + water }=\mathrm{ab}+\mathrm{ep}+\mathrm{qz}+\mathrm{chl} \\
& 10\left(\mathrm{Na}_{0.8}, \mathrm{Ca}_{0.2}\right) \mathrm{Al}_{1.2} \mathrm{Si}_{2.8} \mathrm{O}_{8}+6(\mathrm{Fe}, \mathrm{Mg}) \mathrm{SiO}_{3}+4.5 \mathrm{H}_{2} \mathrm{O}+0.25 \mathrm{O}_{2} \\
& =8 \mathrm{NaAlSi}_{3} \mathrm{O}_{8}+\mathrm{Ca}_{2} \mathrm{FeAl}_{2} \mathrm{Si}_{3} \mathrm{O}_{12}(\mathrm{OH}) \\
& \quad+4 \mathrm{SiO}_{2}+(\mathrm{Mg}, \mathrm{Fe})_{5} \mathrm{Al}_{2} \mathrm{Si}_{3} \mathrm{O}_{10}(\mathrm{OH})_{8}
\end{aligned}
$$

This reaction is consistent with the production of a far greater volume of albitized plagioclase than epidote. However, the textures indicate that this retrogression occurs in at least two stages that are spatially and temporally separated in the gneisses and involve significant metasomatic transfer between reaction sites (see Figure 9). The major element chemistry of the epidote-bearing gneisses is similar to the original unaltered metabasic gneisses in the Lewisian complex (see Figure 8) and of intermediate composition between the albite gneisses and the epidosites. As such, there may be minimal metasomatic change overall, but due to the spatial distribution of the retrogression, extreme changes occur on a local scale.

Early stages of greenschist-facies alteration in the gneisses from Iona are characterized by pervasive albitization of 
plagioclase and replacement of peak metamorphic granoblastic pyroxene by chlorite aggregates (see Figure 9). There is no textural evidence to suggest that significant volumes of other minerals are involved at either of these reaction sites, although fluids and solutes are required. Thus, a reaction such as

$$
\begin{aligned}
& \text { olg + opx }+ \text { water }=\mathrm{ab}+\mathrm{chl} \\
& 10\left(\mathrm{Na}_{0.8}, \mathrm{Ca}_{0.2}\right) \mathrm{Al}_{1.2} \mathrm{Si}_{2.8} \mathrm{O}_{8}+5(\mathrm{Fe}, \mathrm{Mg}) \mathrm{SiO}_{3}+2 \mathrm{Na}^{+}{ }_{(\mathrm{aq})}+4 \mathrm{H}_{2} \mathrm{O} \\
& =10 \mathrm{NaAlSi}_{3} \mathrm{O}_{8}+(\mathrm{Mg}, \mathrm{Fe})_{5} \mathrm{Al}_{2} \mathrm{Si}_{3} \mathrm{O}_{10}(\mathrm{OH})_{8}+2 \mathrm{Ca}_{(\mathrm{aq})}^{2+}+0.5 \mathrm{O}_{2}
\end{aligned}
$$

represents the early reaction history and buffers the evolution of fluid composition at the reaction sites. Although this reaction could be written to balance $\mathrm{Na}$, both solid products form as pseudomorphs after the two mineral reactants. This together with the lack of any significant disturbance to the granoblastic texture points to no major change in the modal proportion of the feldspar. Consequently, it is thought probable that $\mathrm{Na}$ is introduced in a fluid phase and, in the frequent absence of other local Ca-bearing retrograde phases, Ca removed without significant volume change of the feldspar during a coupled dissolution-reprecipitation reaction $[60,61]$. Cataclasite-bearing faults seem the most likely conduits for the introduction of Na-bearing fluids into the basement gneisses. The $\mathrm{Na}$ and $\mathrm{Ca}$ budget may in part be locally buffered by the early production of epidosite along such faults, although epidote production in the host gneiss itself postdates albite formation. The production of chlorite from original pyroxene may be coupled to the albitization reaction (2). This would reduce the extent of Si- and Al-movement associated with a change in the plagioclase composition alone.

Apart from the extreme alteration experienced in the epidosites, the localized epidotization in the host gneisses shares the same pseudomorphic one-for-one replacement texture with the earlier reactions. Hence, the formation of epidote at the expense of albite (3) must also be coupled to metasomatic change involving loss of $\mathrm{Na}$ and addition of $\mathrm{Ca}, \mathrm{Fe}$, and water:

$$
\begin{aligned}
& \mathrm{ab}+\text { water }=\mathrm{ep}+\mathrm{qz} \\
& \begin{array}{l}
4 \mathrm{NaAlSi}_{3} \mathrm{O}_{8}+4 \mathrm{Ca}^{2+}{ }_{(\mathrm{aq})}+2 \mathrm{Fe}_{(\mathrm{aq})}^{2+}+\mathrm{H}_{2} \mathrm{O}+2.5 \mathrm{O}_{2} \\
=2 \mathrm{Ca}_{2} \mathrm{FeAl}_{2} \mathrm{Si}_{3} \mathrm{O}_{12}(\mathrm{OH})+4 \mathrm{Na}_{(\mathrm{aq})}^{+}+6 \mathrm{SiO}_{2}
\end{array}
\end{aligned}
$$

This requirement for movement of $\mathrm{Na}$ and $\mathrm{Ca}$ also provides support to the suggestion that the plagioclase replacement reaction (2) may not be a closed system with respect to Na. During the alteration of albite to epidote, quartz may be produced (3), although largely this appears to be lost in solution. Hence, it is represented by quartz veins that are relatively abundant in the more intensely altered gneisses (see Figure 3(d)) and quartz blebs where the texture is less disturbed by later deformation (see Figure 7(f)).

The spatial decoupling of the different retrograde reactions may be a characteristic response of basement gneisses to fluid infiltration and highlights a distinction between prograde and retrograde behaviour. Fluids are typically released at prograde reaction sites, and their chemistry is controlled at the reaction site [62]. Hence, solutes are delivered directly to local sites of product formation. In contrast, retrograde equilibria are kinetically difficult and dominated by pseudomorphic replacement textures that lack local chemical balance [63]. With retrograde processes, fluid chemistry may be subject to "external" controls, and as such, key soluble reactants may be lacking at potential reaction sites.

6.2. Controls on the Spatial Distribution of Retrogression. Large fracture systems commonly provide conduits for fluid and are particularly prone to alteration (see Figure 9) (e.g., $[20,64])$. The cataclastic textures of relict minerals within epidosite, its overall brecciated texture point, and the planar geometry of the epidosite point towards replacement of fault rock and importantly reactivation of these structures. As such, there is a strong link between deformation and fluid access to the gneisses $(c f$. $[5,20])$, and there are alternations between mineralization and fault activity.

Spatial separation of albite-rich and epidote-rich assemblages linked to hydrothermal alteration is reported in basaltic host lithologies, where epidote is formed in conduits of high-temperature fluids and successive phases of alteration are linked to different fluids [12, 65]. Whilst a model of high-temperature fluids moving along faults could potentially account for some of the larger planer epidosites ( $c f$. [66]), this seems an unlikely explanation for the generation of the more pervasive styles of epidotization in the epidotebearing gneisses. The latter have a highly complex distribution relative to the albite gneisses and lack a simple geometric relationship to epidote-bearing veins and cataclasites.

The pseudomorphic replacement of initial oligoclase by albite and then albite by epidote occurs in environments where fluids may transport cations to and from reaction sites, and hence, the overall textural configuration remains largely unmodified. The pervasive formation of albite and chlorite and the lack of a spatial association with either veins or cataclasites indicate that fluids had access to all parts of the gneiss along a relatively permeable grain boundary network and through intergranular pore networks in the feldspar [27]. Ca will be available at the reaction sites producing albite, and hence, there might be an expectation of a small volume of epidote (1) in the immediate vicinity ( $c f$. [67]). This would require both the fluid to be supersaturated with respect to epidote, and any kinetic hurdles with epidote nucleation must be satisfied. However, epidote, or indeed any other Ca-bearing phase, does not form in many of these locations, and epidote is developed elsewhere over a much more limited spatial extent (e.g., [68]). Hence, there must either be a kinetic impediment that is not overcome whilst the reactants are together or epidote formation is enhanced in specific locations far from the site of $\mathrm{Ca}$ release. The latter could include preferential nucleation within nearby epidote-bearing lithologies such as the early cataclasites. This may be enough to allow the local separation of reaction products (e.g., [69-71]), although perhaps not the scale of separation. 
The replacement of retrograde albite by later epidote within the host gneisses implies temporal separation as well as spatial separation of the retrograde reactions. Temporal separation could be triggered by influx of new fluid, but there is no evidence for a change in fluid chemistry from the early vein assemblage, and crucial epidotization occurs in a series of replacement events in both the cataclasites and the host gneisses. Hence, temporal separation implies a likely change in the availability of reactants during the reaction process that is coupled to the kinetic restrictions on epidote formation outlined above.

Many smaller structural discontinuities in the metabasic gneisses, even those with evidence of both cataclasis and fluid presence, do not enhance pervasive wall rock alteration (see Figure 3(b)) and instead appear to spatially limit production of epidote in the host. As such, the concept of a permeable damage zone on either side of the fracture core [72] does not "hold much water" in such lithologies. Epidote veins often mark the boundaries of pervasively altered gneiss, with one side of the vein lacking epidote alteration (see Figures 2(c), 7(a), and 9). Equally epidote-bearing gneisses may occur away from epidosites and are characterized by few fractures (see Figure 3(c)). The most notable feature of the reaction fronts between completely epidotized, and completely unmodified, albite is the sharpness of the transitions, either when subjected to a structural control (see Figures 1(c), 6(a), and 8) or when away from the influence of fractures (see Figure 1(d)). In the absence of hightemperature gradients to drive this contrast in behaviour (cf. [64]), it seems likely that deformation must play a key role in allowing the influx or removal of fluids. The asymmetrical development of epidote around fractures can be explained by them acting as bounding planes separating areas where permeability is structurally enhanced [73]. As such, a mesh of open channels could be present between bounding shear planes. Consequently, many of the epidotemineralized cataclasites and veins act as zones where fluid is extracted from the gneiss (see Figure 9), and focused flow may effectively provide the limitations on pervasive flow.

The later tensile calcite-quartz hydrothermal veins also lack any association with alteration of the adjacent host gneiss. Conditions of tensile and earlier shear fractures appear to be similar with greenschist-facies mineralogy developed for both. Fluids must be associated with these veins, but a relatively static system seems probable given the spatial distribution of the mineral fill correlates so close with the mineralogy of the wall rock (see Figures 6(e) and $6(\mathrm{~g}))$. The variation in vein fill indicates that very localized interaction with the adjacent wall rock minerals occurs [59] with no modification of the wall rocks. This implies that the wall rock mineralogy may exert control on nucleation rather than providing key components for the vein fill. However, the combination of open fractures with or without shear deformation, plus fluids on those fractures, plus appropriate $\mathrm{P}-\mathrm{T}$ conditions is not enough to trigger pervasive alteration in the host rock. As such, retrograde reaction rates in fluidpresent conditions appear to be slow (cf. [74]), and the fluid presence in itself is not the key factor controlling some of the retrograde reactions. If this also applies to the epidote ret- rogression, then given the lack of structural constraint on many of these reaction fronts, apparently similar thermal and barometric conditions, and an otherwise uniform host lithology, the fronts are likely to reflect limited availability of reactants, either of fluid or potentially of $\mathrm{Ca}^{2+}$ ions. This will be constrained not by mobility of the cations involved but by their ease of consumption in retrograde reactions coupled to the reactive potential of the host lithologies [74]. Transient availability of reactants in this environment is possible during active deformation allowing periodic influx or removal of fluids via some elements of the fracture or grain boundary network.

6.3. Reaction-Enhanced or Reaction-Restricted Permeability and the Role of Deformation. Local permeability may be modified through the volume changes due to metamorphic reactions [25-27]. The net retrograde reaction (1) appears to approach geochemical balance other than the addition of water (see Figure 8), and overall hydration would result in a ca. $4 \%$ increase in volume of solid product phases (epidote+chlorite+albite+quartz) relative to reactants (oligoclase+pyroxene), although much of the quartz may be lost in the fluid phase. However, textures suggest that the retrograde processes involve a series of spatially disconnected reactions. Consequently, significant metasomatic transfer of cations between dispersed reaction sites is implied, and solid volume changes will be correspondingly heterogeneous. The one-to-one pseudomorphic replacement textures allow local scale comparison of molar volumes of the solid phases $[61,70]$.

The greenschist-facies retrograde products albite, chlorite, and epidote each create distinctive textures due to their volume relative to the phases that they replace. Albite has a very similar molar volume to the oligoclase [75], and chlorite has a larger volume than pyroxene (ca. 35\% increase) [76, 77] in a reaction with an assumed constant $(\mathrm{Mg}, \mathrm{Fe})$. Thus, early retrograde history (2) would be characterized by a ca. 4.3$4.7 \%$ volume increase in the solid phases, with the uncertainty reflecting the full range of possible orthopyroxene and chlorite end-member compositions. Hence, the volume change is not very sensitive to the mineral compositions of chlorite and orthopyroxene or of the original plagioclase [75]. If this reaction was a closed system with respect to $\mathrm{Na}$, involving a corresponding change in the modal proportions of feldspar, then this would be associated with a ca. 7.6$8.3 \%$ volume decrease in the retrograde phases. Although as discussed earlier there is no textural evidence to support this scenario. Epidote $\left(X_{\mathrm{Fe}}=0.3\right)$ pseudomorphic replacement of albite, with assumed constant $\mathrm{Al}$ and excess Si lost in solution, is associated with a decrease in volume of ca. 30\% [78, 79]. If all quartz is retained at the reaction site (3), then a modest ca. $4 \%$ increase in volume occurs, although in the vast majority of instances, there is no textural evidence to support this scenario. The spatial separation of reaction products dictates that these characteristics have strong control on the distribution of pervasive alteration that is not structurally constrained (e.g., [70]). During the pseudomorphic replacement of pyroxene, the excess higher volume chlorite produced may migrate to the grain boundaries of the gneiss 
(see Figure 9), restrict permeability and porosity, and inhibit subsequent pervasive alteration $[25,80]$.

In contrast to the early pervasive alteration of the gneisses, the production of epidote is spatially restricted ( $c f$. [68]). Generation of relatively fine-grained reaction products will enhance permeability by the creation of grain boundaries, so the reaction itself has a tendency to proceed to completion (see Figure 9). Crucial volume reduction associated with the replacement of albite by epidote $[12,13,68]$ may draw fluids in towards the reaction front $[25,26$, 81]. Fracture systems may also be generated by such local volume changes [25]. The preservation of the granoblastic texture of the original gneiss points to isovolumetric replacement with little structural modification [82], and such behaviour depends on the existence of a framework of amphibole in the metabasic gneisses that can resist compaction ( $c f$. [83]). Coarse-grained amphibolites are widely recognized as being stronger than quartzofeldspathic rocks in most crustal conditions, and the absence of a strong amphibole fabric suggests that dissolution-precipitation creep was limited in these gneisses [84-88]. Such volume reduction associated with the solid phases would further limit the spatial extent of the epidotization, by sucking Ca-bearing fluids towards the reaction site $[13,68,83,89]$ creating local concentrations of epidote (see Figure 9). Reaction-enhanced permeability will also withdraw fluids from the fracture systems [25] responsible for the reintroduction of fluids, limiting the ability of reactions to start on many fracture margins (see Figure 9). This may account for the complex distribution of epidote within the host gneisses and the lack of a clear spatial link to fractures.

The retrogression of these metabasic gneisses is characterized by the separate spatial and temporal development of reaction products. Accounting for this separation is crucial to understanding the fluid movement in the basement rocks. The replacement of oligoclase by albite probably occurs through a coupled dissolution-reprecipitation process [75] and may be kinetically more straightforward than the replacement of albite by epidote. Relative to the early formation of albite and chlorite, the formation of epidote in the host gneisses is localized and may be dependent on active deformation to overcome the kinetic restrictions. This is also suggested by the association between cataclasite-bearing faults and the formation of epidosite. Equally, the scale of heterogeneity in the development of epidote-rich gneiss suggests that movement of Ca-rich fluids occurs. Consequently, the spatial distribution of epidote in the host gneiss is unlikely to be solely generated by locally restricted nucleation of the low volume reaction products. Ca-bearing fluids generated during albitization could be drawn back into temporally high permeability damage zones and fault cores during renewed movement on those faults $[34,35,90,91]$ and away from the surrounding albite-rich host gneisses (see Figure 9). The latter would have restricted permeability in the unfractured areas of gneiss due to the coating of grain boundaries by chlorite (see Figure 9). It is uncertain whether lower fluid pressure during fault movement could influence solubility of epidote within the fluid phase (cf. [35]) and hence play a role in its distribution. Fluid pressure cycling during coseismic events and interseismic periods may allow fluids to be alternately drawn into and expelled from the fault zones [34, 90, 91]. This provides a mechanism for generating Na-rich fluids in the epidote-producing reactions near the faults that could then be moved into the distal areas as a consequence of the increased fluid pressure, to produce more albite (see Figure 9). Such behaviour would imply that in relatively low permeability basement, changes in fluid distribution driven by tectonism might be more rapid than the response of rocks to some kinetically difficult metamorphic reactions.

6.4. Controls on Crustal Permeability. Metasomatism of oceanic crust commonly involves migration of $\mathrm{Ca}, \mathrm{Na}$, and $\mathrm{Mg}$ and development of low variance greenschist-facies mineral assemblages $[12,13,29,38,64,65,68]$. Pervasive albitization away from epidote-bearing fracture systems is a characteristic also commonly observed in such permeable host rocks (e.g., [92]). Availability of solutes, such as $\mathrm{Ca}$, is less likely to be a factor in the large-scale, long-lived hydrothermal systems present in shallow crustal levels.

In many ways, the alteration of metabasic gneisses is similar to that of basalts in the shallow crust [64], although in the former there is more local control by brittle deformation on fluid movements in otherwise low permeability rocks (e.g., [93]) and a closer approach to closed system behaviour. There is also less potential for local variations in geothermal conditions ( $c f$. [64]) in basement rocks lacking proximal heat sources. Faulting and stress cycling of relatively impermeable host rocks has more potential to influence local fluid pressures and the resulting metamorphic reactions. Retrograde volume changes occur within a mechanically strong mineralogical framework and strongly control the evolving permeability [80, 94]. The evolution of permeability in such gneisses may be applicable to the behaviour of mafic lower crustal rocks in ambient greenschist-facies conditions. Whilst processes involved in the eclogitization of granulites $[27,80,94]$ are analogous to the volume changes associated with epidotization, the reactions studied here may be of significance to controls on behaviour of normal thickness continental crust. The conversion of plagioclase to epidote may draw fluids in towards the resulting porosity and hence focus the fluid in patches of epidote gneiss and the epidosites. The resulting heterogeneity may then influence subsequent structural evolution ( $c f$. [8]).

Granitic gneiss has very different permeability characteristics to the metabasic gneiss. Whilst the abundance of albite makes the former prone to epidotization in the presence of a Ca-bearing fluid, they are less able to support the retrograde volume changes during reaction in the likely absence of a strong framework of unaltered phases (e.g., amphibole). Consequently, granitic gneisses are dominated by intense retrogression associated with deformation-enhanced permeability along fracture planes ( $c f .[20])$, rather than reactionenhanced permeability that will dominate the metabasic gneisses. Equally, despite the abundance of plagioclase in the nearby meta-anorthosite of Iona, there is little pervasive epidotization in most exposures, presumably because of the lack of a supporting framework to allow retrograde volume changes to draw fluids into the main body of the rock. 


\section{Conclusions}

The complex spatial distribution of retrograde greenschistfacies reaction products in basement gneisses reflects a combination of deformation-controlled fluid access and permeability controlled by the volume of the pseudomorphic reaction products themselves. Initial fluid influx causes widespread albitization and chloritization of the original plagioclase-pyroxene-bearing, amphibole-rich metabasic gneisses, which restricts permeability and generates a Ca-rich fluid. Subsequently, epidote crystallizes from this fluid but is in contrast extremely localized and replaces either albite in patches of the host gneisses or cataclasites within prominent fault structures. This localization may initially develop as a consequence of kinetic controls on the nucleation of epidote coupled to the migration of the Ca-rich fluids possibly in response to deformation cycles associated with the brittle faulting. These spatial restrictions are then strongly augmented by reaction-enhanced permeability associated with the replacement of albite by epidote. The combination of processes results in a spatial and temporal decoupling of retrograde reaction products. This includes the local buffering of fluid compositions facilitating significant metasomatic transfer of $\mathrm{Ca}$ and $\mathrm{Na}$ between reaction sites. Such behaviour seems likely to be a characteristic response of metabasic gneisses to greenschist-facies retrogression and contrasts with granitic gneisses where the lack of a strong amphibolerich matrix restricts the influence of reaction-enhanced permeability. Hence, in granitic gneisses, epidotization is largely restricted to fracture networks.

This study of fluid transfer within a reactive host lithology represents the first account of the balance between deformation and reaction control on the evolution of permeability in basement gneiss.

\section{Data Availability}

Samples and thin sections used in this study are deposited in The Hunterian, University of Glasgow.

\section{Disclosure}

Daniel Koehn's present address is GeoZentrum Nordbayern, University of Erlangen-Nuremberg, 91054 Erlangen, Germany.

\section{Conflicts of Interest}

The authors declare that there is no conflict of interest regarding the publication of this paper.

\section{Acknowledgments}

Peter Chung, Robert McDonald, and John Gilleece are thanked for their technical assistance. ADH is supported through a $\mathrm{PhD}$ studentship, funded by the University of Glasgow and NERC, as part of the NERC Centre for Doctoral Training in Oil and Gas (NEM00578X/1). We are grateful for their financial support of this project. Bruce Yardley and
Yann Rolland are thanked for their helpful and thoughtful comments on earlier drafts of the manuscript.

\section{References}

[1] H. Austrheim, "Eclogitization of lower crustal granulites by fluid migration through shear zones," Earth and Planetary Science Letters, vol. 81, no. 2-3, pp. 221-232, 1987.

[2] L. Bettison-Varga, R. J. Varga, and P. Schiffman, "Relation between ore-forming hydrothermal systems and extensional deformation in the Solea graben spreading center, Troodos ophiolite, Cyprus," Geology, vol. 20, no. 11, pp. 987-990, 1992.

[3] T. J. Dempster and C. Persano, "Low-temperature thermochronology: resolving geotherm shapes or denudation histories?," Geology, vol. 34, no. 2, pp. 73-76, 2006.

[4] B. N. Eisenlohr, D. Groves, and G. A. Partington, "Crustalscale shear zones and their significance to Archaean gold mineralization in Western Australia," Mineralium Deposita, vol. 24, no. 1, 1989.

[5] M. A. Etheridge, V. J. Wall, and R. H. Vernon, "The role of the fluid phase during regional metamorphism and deformation," Journal of Metamorphic Geology, vol. 1, no. 3, pp. 205-226, 1983.

[6] J. A. Jackson, H. Austrheim, D. McKenzie, and K. Priestley, "Metastability, mechanical strength, and the support of mountain belts," Geology, vol. 32, no. 7, pp. 625-628, 2004.

[7] C. L. Kirkland, C. V. Spaggiari, R. H. Smithies et al., "The affinity of Archean crust on the Yilgarn-Albany-Fraser orogen boundary: implications for gold mineralisation in the Tropicana zone," Precambrian Research, vol. 266, pp. 260-281, 2015.

[8] S. E. M. Lawther, T. J. Dempster, Z. K. Shipton, and A. J. Boyce, "Effective crustal permeability controls fault evolution: an integrated structural, mineralogical and isotopic study in granitic gneiss, Monte Rosa, northern Italy," Tectonophysics, vol. 690, pp. 160-173, 2016.

[9] I. K. Pitcairn, A. D. L. Skelton, C. Broman, F. Arghe, and A. Boyce, "Structurally focused fluid flow during orogenesis: the Islay anticline, SW highlands, Scotland," Journal of the Geological Society, London, vol. 167, no. 4, pp. 659-674, 2010.

[10] R. H. Sibson, "Arterial faults and their role in mineralizing systems," Geoscience Frontiers, vol. 10, no. 6, pp. 2093-2100, 2019.

[11] A. D. L. Skelton, C. M. Graham, and M. J. Bickle, "Lithological and structural controls on regional 3-D fluid flow patterns during greenschist facies metamorphism of the Dalradian of the SW Scottish Highlands," Journal of Petrology, vol. 36, no. 2, pp. 563-586, 1995.

[12] L. Bettison-Varga, P. Schiffman, and D. R. Janecky, "Fluidrock interaction in the hydrothermal upflow zone of the Solea graben, Troodos ophiolite, Cyprus," Geological Society of America, Special Paper, vol. 296, pp. 81-111, 1995.

[13] J. R. Cann, A. M. McCaig, and B. W. D. Yardley, "Rapid generation of reaction permeability in the roots of black smoker systems, Troodos ophiolite, Cyprus," Geofluids, vol. 15, no. 1-2, pp. 179-192, 2015.

[14] T. B. Kristensen, A. Rotevatn, D. C. P. Peacock, G. A. Henstra, I. Midtkandal, and S. A. Grundvåg, "Structure and flow properties of syn-rift border faults: the interplay between fault damage and fault-related chemical alteration (Dombjerg fault, 
Wollaston Forland, NE Greenland)," Journal of Structural Geology, vol. 92, pp. 99-115, 2016.

[15] C. J. Richardson, J. R. Cann, H. G. Richards, and J. G. Cowan, "Metal-depleted root zones of the Troodos ore-forming hydrothermal systems, Cyprus," Earth and Planetary Science Letters, vol. 84, no. 2-3, pp. 243-253, 1987.

[16] J. J. Ague, "Extreme channelization of fluid and the problem of element mobility during Barrovian metamorphism," American Mineralogist, vol. 96, no. 2-3, pp. 333-352, 2011.

[17] J. M. Ferry, "Role of fluid flow in the contact metamorphism of siliceous dolomitic limestones," American Mineralogist, vol. 80, pp. 719-736, 1994.

[18] B. I. Kleine, I. K. Pitcairn, and A. D. L. Skelton, "Mineralogical controls on metamorphic fluid flow in metabasaltic sills from Islay, Scotland," Lithos, vol. 248-251, pp. 22-39, 2016.

[19] N. H. S. Oliver, "Review and classification of structural controls on fluid flow during regional metamorphism," Journal of Metamorphic Geology, vol. 14, no. 4, pp. 477-492, 1996.

[20] Y. Rolland and M. Rossi, "Two-stage fluid flow and element transfers in shear zones during collision burial-exhumation cycle: insights from the Mont Blanc Crystalline Massif (Western Alps)," Journal of Geodynamics, vol. 101, pp. 88-108, 2016.

[21] N. P. Laverov, S. V. Yudintsev, B. T. Kochkin, and V. I. Malkovsky, "The Russian strategy of using crystalline rock as a repository for nuclear waste," Elements, vol. 12, no. 4, pp. 253-256, 2016.

[22] A. E. Milodowski, M. R. Gillespie, and S. J. Kemp, A Review of Fracture Mineralogy and Mineral Distribution in the Sellafield Boreholes, British Geological Survey Report to Nirex, 2000.

[23] I. Cartwright, W. L. Power, N. H. S. Oliver, R. K. Valenta, and G. S. McLatchie, "Fluid migration and vein formation during deformation and greenschist facies metamorphism at Ormiston Gorge, central Australia," Journal of Metamorphic Geology, vol. 12, no. 4, pp. 373-386, 1994.

[24] B. W. D. Yardley, D. E. Harlov, and W. Heinrich, "Rates of retrograde metamorphism and their implications for crustal rheology," Geofluids, vol. 10, 240 pages, 2010.

[25] B. Jamtveit, A. Malthesorenssen, and O. Kostenko, "Reaction enhanced permeability during retrogressive metamorphism," Earth and Planetary Science Letters, vol. 267, no. 3-4, pp. 620-627, 2008.

[26] N. Marchildon and G. M. Dipple, "Irregular isograds, reaction instabilities, and the evolution of permeability during metamorphism," Geology, vol. 26, no. 1, pp. 15-18, 1998.

[27] A. Putnis and H. Austrheim, "Fluid-induced processes: metasomatism and metamorphism," Geofluids, vol. 10, 269 pages, 2010.

[28] P. H. G. M. Dirks, E. G. Charlesworth, M. R. Munyai, and R. Wormald, "Stress analysis, post-orogenic extension and 3.01Ga gold mineralisation in the Barberton Greenstone Belt, South Africa," Precambrian Research, vol. 226, pp. 157-184, 2013.

[29] S. A. Gilgen, L. W. Diamond, and I. Mercolli, "Sub-seafloor epidosite alteration: timing, depth and stratigraphic distribution in the Semail ophiolite, Oman," Lithos, vol. 260, pp. 191-210, 2016.

[30] J. J. Ague, "Mass transfer during Barrovian metamorphism of pelites, south-central Connecticut; II, channelized fluid flow and the growth of staurolite and kyanite," American Journal of Science, vol. 294, no. 9, pp. 1061-1134, 1994.
[31] N. H. S. Oliver and P. D. Bons, "Mechanisms of fluid flow and fluid-rock interaction in fossil metamorphic hydrothermal systems inferred from vein-wallrock patterns, geometry and microstructure," Geofluids, vol. 1, no. 2, pp. 137-162, 2001.

[32] R. L. Rudnick and D. M. Fountain, "Nature and composition of the continental crust: a lower crustal perspective," Reviews of Geophysics, vol. 33, no. 3, pp. 267-309, 1995.

[33] G. Zandt and C. J. Ammon, "Continental crust composition constrained by measurements of crustal Poisson's ratio," Nature, vol. 374, no. 6518, pp. 152-154, 1995.

[34] S. F. Cox, "Faulting processes at high fluid pressures: an example of fault valve behavior from the Wattle Gully Fault, Victoria, Australia," Journal of Geophysical Research, vol. 100, no. B7, pp. 12841-12859, 1995.

[35] W. T. Parry, "Fault-fluid compositions from fluid-inclusion observations and solubilities of fracture-sealing minerals," Tectonophysics, vol. 290, no. 1-2, pp. 1-26, 1998.

[36] D. K. Bird and A. R. Spieler, "Epidote in geothermal systems," Reviews in Mineralogy and Geochemistry, vol. 56, no. 1, pp. 235-300, 2004.

[37] K. M. Gillis and G. Thompson, "Metabasalts from the midAtlantic ridge: new insights into hydrothermal systems in slow-spreading crust," Contributions to Mineralogy and Petrology, vol. 113, no. 4, pp. 502-523, 1993.

[38] N. Marks, P. Schiffman, R. A. Zierenberg, H. Franzson, and G. Ó. Fridleifsson, "Hydrothermal alteration in the Reykjanes geothermal system: insights from Iceland deep drilling program well RN-17," Journal of Volcanology and Geothermal Research, vol. 189, no. 1-2, pp. 172-190, 2010.

[39] M. J. Mottl, "Metabasalts, axial hot springs, and the structure of hydrothermal systems at mid-ocean ridges," Geological Society of America Bulletin, vol. 94, no. 2, pp. 161-180, 1983.

[40] F. M. Fraser, The Lewisian and Torridonian geology of Iona, [Ph.D. thesis], University of St. Andrews, 1977.

[41] R. G. Park, “The Lewisian terrane model: a review," Scottish Journal of Geology, vol. 41, no. 2, pp. 105-118, 2005.

[42] R. G. Park, A. D. Stewart, and D. T. Wright, "The Hebridean terrane," in The Geology of Scotland, N. H. Trewin, Ed., pp. 45-80, The Geological Society, London, UK, 2002.

[43] C. A. McAteer, J. S. Daly, M. J. Flowerdew, M. J. Whitehouse, and N. M. Monaghan, "Sedimentary provenance, age and possible correlation of the Iona Group SW Scotland," Scottish Journal of Geology, vol. 50, pp. 143-158, 2014.

[44] G. J. H. Oliver, S. A. Wilde, and Y. Wan, "Geochronology and geodynamics of Scottish granitoids from the late Neoproterozoic break-up of Rodinia to Palaeozoic collision," Journal of the Geological Society, London, vol. 165, no. 3, pp. 661-674, 2008.

[45] G. J. Potts, R. H. Hunter, A. L. Harris, and F. M. Fraser, "Lateorogenic extensional tectonics at the NW margin of the Caledonides in Scotland," Journal of the Geological Society, London, vol. 152, no. 6, pp. 907-910, 1995.

[46] B. J. Bluck, T. J. Dempster, and G. Rogers, "Allochthonous metamorphic blocks on the Hebridean passive margin, Scotland," Journal of the Geological Society, vol. 154, no. 6, pp. 921-924, 1997.

[47] J. Wheeler, R. G. Park, H. R. Rollinson, and A. Beach, "The Lewisian complex: insights into deep crustal evolution," in Continental Tectonics and Mountain Building: The Legacy of Peach and Horne, R. Law, R. W. H. Butler, R. E. Holdsworth, 
M. Krabbendam, and R. Strachan, Eds., vol. 355 of Geological Society, pp. 81-101, Special Publication, London, UK, 2010.

[48] A. Beach, "Retrogressive metamorphic processes in shear zones with special reference to the Lewisian complex," Journal of Structural Geology, vol. 2, no. 1-2, pp. 257-263, 1980.

[49] J. Imber, R. E. Holdsworth, C. A. Butler, and G. E. Lloyd, "Fault-zone weakening processes along the reactivated outer Hebrides fault zone, Scotland," Journal of the Geological Society, London, vol. 154, no. 1, pp. 105-109, 1997.

[50] S. A. Drury, "Chemical changes during retrogressive metamorphism of Lewisian granulite facies rocks from Coll and Tiree," Scottish Journal of Geology, vol. 10, no. 3, pp. 237256, 1974.

[51] N. H. Woodcock and K. Mort, "Classification of fault breccias and related fault rocks," Geological Magazine, vol. 145, no. 3, pp. 435-440, 2008.

[52] J. Imber, R. E. Holdsworth, C. A. Butler, and R. A. Strachan, “A reappraisal of the Sibson-Scholz fault zone model: the nature of the frictional to viscous ("brittle-ductile") transition along a long-lived, crustal-scale fault, outer Hebrides, Scotland," Tectonics, vol. 20, no. 5, pp. 601-624, 2001.

[53] R. H. Sibson, "Generation of pseudotachylyte by ancient seismic faulting," Geophysical Journal International, vol. 43, no. 3, pp. 775-794, 1975.

[54] S. P. Kelley, S. M. Reddy, and R. Maddock, "Laser-probe 40Ar/39Ar investigation of a pseudotachylyte and its host rock from the outer isles thrust, Scotland," Geology, vol. 22, no. 5, pp. 443-446, 1994.

[55] S. E. M. Lawther and T. J. Dempster, “Apatite grain boundary morphology and its response to low-temperature fluid infiltration in crystalline basement," Geofluids, vol. 9, no. 3, pp. 224236, 2009.

[56] J. G. Holland and R. S. J. Lambert, "Comparative major element geochemistry of the Lewisian of mainland of Scotland," in The Early Precambrian of Scotland and Related Rocks of Greenland, R. G. Park and J. Tarney, Eds., pp. 51-62, University of Keele", 1973.

[57] R. H. Grapes and P. W. O. Hoskin, "Epidote group minerals in low-medium pressure metamorphic terranes," Reviews in Mineralogy and Geochemistry, vol. 56, no. 1, pp. 301-345, 2004.

[58] I. J. Richards, J. B. Connelly, R. T. Gregory, and D. R. Gray, "The importance of diffusion, advection, and host-rock lithology on vein formation: a stable isotope study from the Paleozoic Ouachita orogenic belt, Arkansas and Oklahoma," Geological Society of America, Bulletin, vol. 114, no. 11, pp. 1343-1355, 2002.

[59] B. W. D. Yardley and S. H. Bottrell, "Silica mobility and fluid movement during metamorphism of the Connemara schists, Ireland," Journal of Metamorphic Geology, vol. 10, pp. 453464, 1992.

[60] O. Plümper, A. Botan, C. Los, Y. Liu, A. Malthe-Sørenssen, and B. Jamtveit, "Fluid-driven metamorphism of the continental crust governed by nanoscale fluid flow," Nature Geoscience, vol. 10, no. 9, pp. 685-690, 2017.

[61] A. Putnis, "Transient porosity resulting from fluid-mineral interaction and its consequences," Reviews in Mineralogy and Geochemistry, vol. 80, no. 1, pp. 1-23, 2015.

[62] B. W. D. Yardley, "The role of water in the evolution of the continental crust," Journal of the Geological Society, London, vol. 166, pp. 585-600, 2009.
[63] G. J. Corbett and G. N. Phillips, "Regional retrograde metamorphism of a high grade terrain: the Willyama complex, Broken Hill, Australia," Lithos, vol. 14, no. 1, pp. 59-73, 1981.

[64] D. Bosch, M. Jamais, F. Boudier, A. Nicolas, J. M. Dautria, and P. Agrinier, "Deep and high-temperature hydrothermal circulation in the Oman ophiolite-petrological and isotopic evidence," Journal of Petrology, vol. 45, no. 6, pp. 1181-1208, 2004.

[65] N. M. Rose and D. K. Bird, "Hydrothermally altered dolerite dykes in East Greenland: implications for Ca-metasomatism of basaltic protoliths," Contributions to Mineralogy and Petrology, vol. 116, no. 4, pp. 420-432, 1994.

[66] W. F. Giggenbach, "Mass transfer in hydrothermal alteration systems - a conceptual approach," Geochimica et Cosmochimica Acta, vol. 48, no. 12, pp. 2693-2711, 1984.

[67] L. L. Pryer and P.-. Y. F. Robin, "Retrograde metamorphic reactions in deforming granites and the origin of flame perthite," Journal of Metamorphic Geology, vol. 13, pp. 645658, 1995.

[68] F. Arghe, A. Skelton, and I. Pitcairn, "Spatial coupling between spilitization and carbonation of basaltic sills in SW Scottish Highlands: evidence of a mineralogical control of metamorphic fluid flow," Geofluids, vol. 11, no. 3, pp. 245-259, 2011.

[69] D. M. Carmichael, "On the mechanism of prograde metamorphic reactions in quartz-bearing pelitic rocks," Contributions to Mineralogy and Petrology, vol. 20, no. 3, pp. 244-267, 1969.

[70] A. Putnis, "Mineral replacement reactions: from macroscopic observations to microscopic mechanisms," Mineralogical Magazine, vol. 66, no. 5, pp. 689-708, 2002.

[71] T. Widmer and A. B. Thompson, "Local origin of high pressure vein material in eclogite facies rocks of the ZermattSaas-Zone, Switzerland," American Journal of Science, vol. 301, no. 7, pp. 627-656, 2001.

[72] J. S. Caine, J. P. Evans, and C. B. Forster, "Fault zone architecture and permeability structure," Geology, vol. 24, no. 11, pp. 1025-1028, 1996.

[73] R. H. Sibson, "Structural permeability of fluid-driven faultfracture meshes," Journal of Structural Geology, vol. 18, no. 8, pp. 1031-1042, 1996.

[74] B. W. D. Yardley and J. W. Valley, "The petrologic case for a dry lower crust," Journal of Geophysical Research, vol. 102, no. B6, pp. 12173-12185, 1997.

[75] O. Plümper and A. Putnis, "The complex hydrothermal history of granitic rocks: multiple feldspar replacement reactions under subsolidus conditions," Journal of Petrology, vol. 50, no. 5, pp. 967-987, 2009.

[76] R. J. Angel and D. A. Hugh-Jones, "Equations of state and thermodynamic properties of enstatite pyroxenes," Journal of Geophysical Research, vol. 99, no. B10, pp. 19777-19783, 1994.

[77] M. Roots, "Molar volumes on the clinochlore - amesite binary: some new data," European Journal of Mineralogy, vol. 6, no. 2, pp. 279-284, 1994.

[78] M. Gottschalk, "Thermodynamic properties of zoisite, clinozoisite, and epidote," Reviews in Mineralogy and Geochemistry, vol. 56, no. 1, pp. 83-124, 2004.

[79] R. A. Robie and P. M. Bethke, "Molar volumes and densities of minerals," U S Geological Survey Report TEI, vol. 822, 1962.

[80] B. Jamtveit, H. Austrheim, and A. Putnis, "Disequilibrium metamorphism of stressed lithosphere," Earth-Science Reviews, vol. 154, pp. 1-13, 2016. 
[81] B. Jamtveit, C. V. Putnis, and A. Malthe-Sørenssen, "Reaction induced fracturing during replacement processes," Contributions to Mineralogy and Petrology, vol. 157, no. 1, pp. 127133, 2009.

[82] R. H. Vernon, A Practical Guide to Rock Microstructure, Cambridge University Press, 2004.

[83] D. Rumble, J. M. Ferry, T. C. Hoering, and A. J. Boucot, "Fluid flow during metamorphism at the Beaver Brook fossil locality, New Hampshire," American Journal of Science, vol. 282, no. 6, pp. 886-919, 1982.

[84] A. Berger and H. Stunitz, "Deformation mechanisms and reaction of hornblende: examples from the Bergell tonalite (Central Alps)," Tectonophysics, vol. 257, no. 2-4, pp. 149-174, 1996.

[85] X. Huang, W. Bai, and J. Hu, "Experimental studies on elastic and rheological properties of amphibolites at high pressure and high temperature," Science in China Series D: Earth Sciences, vol. 46, no. 12, pp. 1212-1222, 2003.

[86] D. L. Kohlstedt, B. Evans, and S. J. Mackwell, "Strength of the lithosphere: constraints imposed by laboratory experiments," Journal of Geophysical Research-Solid Earth, vol. 100, no. B9, pp. 17587-17602, 1995.

[87] M. A. Pearce, J. Wheeler, and D. J. Prior, "Relative strength of mafic and felsic rocks during amphibolite facies metamorphism and deformation," Journal of Structural Geology, vol. 33, no. 4, pp. 662-675, 2011.

[88] M. R. Stokes, R. P. Wintsch, and C. S. Southworth, "Deformation of amphibolites via dissolution-precipitation creep in the middle and lower crust," Journal of Metamorphic Geology, vol. 30, no. 7, pp. 723-737, 2012.

[89] P. Ortoleva, J. Chadam, E. Merino, and A. Sen, "Geochemical self-organization II: the reactive-infiltration instability," American Journal of Science, vol. 287, no. 10, pp. 1008-1040, 1987.

[90] J. Byerlee, "Model for episodic flow of high-pressure water in fault zones before earthquakes," Geology, vol. 21, no. 4, pp. 303-306, 1993.

[91] R. H. Sibson, "Implications of fault-valve behaviour for rupture nucleation and recurrence," Tectonophysics, vol. 211, no. 1-4, pp. 283-293, 1992.

[92] G. D. Harper, J. R. Bowman, and R. Kuhns, "A field, chemical, and stable isotope study of subseafloor metamorphism of the Josephine ophiolite, California-Oregon," Journal of Geophysical Research, Solid-Earth, vol. 93, no. B5, pp. 4625-4656, 1988.

[93] A. V. Zharikov, V. M. Vitovtova, V. M. Shmonov, and A. A. Grafchikov, "Permeability of the rocks from the Kola superdeep borehole at high temperature and pressure: implication to fluid dynamics in the continental crust," Tectonophysics, vol. 370, no. 1-4, pp. 177-191, 2003.

[94] B. Jamtveit, H. Austrheim, and A. Malthe-Sørenssen, “Accelerated hydration of the Earth's deep crust induced by stress perturbations," Nature, vol. 408, no. 6808, pp. 75-78, 2000.

[95] D. L. Whitney and B. W. Evans, "Abbreviations for names of rock-forming minerals," American Mineralogist, vol. 95, pp. $185-187,2010$. 